\title{
Upper Pleistocene Human Dispersals out of Africa: A Review of the Current State of the Debate
}

\author{
Amanuel Beyin \\ Turkana Basin Institute, Stony Brook University, SBS Building 5th Floor, Stony Brook, NY 11794, USA \\ Correspondence should be addressed to Amanuel Beyin, abeyin@ic.sunysb.edu
}

Received 15 October 2010; Revised 22 January 2011; Accepted 24 February 2011

Academic Editor: Darren Curnoe

Copyright () 2011 Amanuel Beyin. This is an open access article distributed under the Creative Commons Attribution License, which permits unrestricted use, distribution, and reproduction in any medium, provided the original work is properly cited.

\begin{abstract}
Although there is a general consensus on African origin of early modern humans, there is disagreement about how and when they dispersed to Eurasia. This paper reviews genetic and Middle Stone Age/Middle Paleolithic archaeological literature from northeast Africa, Arabia, and the Levant to assess the timing and geographic backgrounds of Upper Pleistocene human colonization of Eurasia. At the center of the discussion lies the question of whether eastern Africa alone was the source of Upper Pleistocene human dispersals into Eurasia or were there other loci of human expansions outside of Africa? The reviewed literature hints at two modes of early modern human colonization of Eurasia in the Upper Pleistocene: (i) from multiple Homo sapiens source populations that had entered Arabia, South Asia, and the Levant prior to and soon after the onset of the Last Interglacial (MIS-5), (ii) from a rapid dispersal out of East Africa via the Southern Route (across the Red Sea basin), dating to 74-60 kya.
\end{abstract}

\section{Introduction}

Central questions to the study of human evolution are when and where modern humans first evolved, and how they colonized areas outside their place of origin [1-5]. Fossil, genetic, and archaeological data currently accumulating from sub-Saharan Africa supports an African origin of modern humans sometime between 200 and 150 kya [6-10], but the timing and the geographic routes along which they migrated out of Africa have never been resolved. Northeast (NE) Africa, Southwest Asia (the Levant), and the Arabian Peninsula have been major foci of research on this topic $[5,11-17]$. So far, the oldest cultural traces and fossil remains of human ancestors have been discovered in East Africa, specifically in Ethiopia [18-20]. With the advent of intensive research on modern human mitochondrial DNA (mtDNA), paleoanthropology attained a turning point; among other things, the genetic data reinforced the Out-of-African origin theory and set possible scenarios for human dispersals [21-23]. African populations display greater genetic diversity, implying that Africa was populated by early human ancestors longer than any other region $[10,21]$. From this, some geneticists hypothesize that all modern human genes descended from a single population-dubbed "African
Eve"-that lived in sub-Saharan Africa around 150 kya [ibid.]. The Levant and the Arabian Peninsula play a central role in the current debate about hominin (humans and their ancestors) dispersal history due to their strategic location at the main gateways of biographic movements between Africa and Eurasia. Both regions have yielded rich Paleolithic and paleontological data that should be useful in any discussions of prehistoric migrations out of Africa and vice versa.

This paper reviews existing archaeological and genetic data from NE Africa (that part of East Africa north of the Equator) and its adjacent regions, to assess the timing and geographic background of Upper Pleistocene (128-12 kya) human colonization of Eurasia. The underlying question is whether eastern Africa alone was the source of Upper Pleistocene human dispersals into Eurasia or were there other loci of human expansions outside of Africa? This analysis differs from that of African versus multiregional originrelated discussions in that this paper focuses specifically on the Upper Pleistocene colonization process of Eurasia by early modern humans (Homo sapiens) as opposed to dealing with the geographic origin of Homo sapiens as a species. The theoretical premise here is that Homo sapiens originated in Africa after 200 kya. The lingering issue is how soon they formed effective founder populations outside of 
Africa. In the context of this paper, the term "dispersal" is used synonymously with the term "migration," and early human dispersal is regarded as a range expansion or niche broadening mechanism in search for stable habitats that, once encountered, become preferred habitats [24, page 251]. The paper concludes with a brief discussion of paleoclimate and coastal habitats in light of their potential role in stimulating prehistoric human dispersals.

The question of what specific conditions stimulated human migration out of Africa has not been satisfactorily answered, but it is important to examine the mechanisms by which early humans successfully colonized Eurasia. Climate change $[25,26]$, population expansion $[3,27]$, increased alliance network [28, 29], projectile technology [29, 30], and the emergence of complex behavior associated with the use of language and symbolism [31-33] have frequently been called upon to explain Upper Pleistocene dispersals out of Africa, but researchers remain divided in testing the contribution of each variable. Some of these traits lack concrete archaeological traces (e.g., language), while others (lithic technology and symbolic relics) are inconsistently represented across regions. The fact that dispersal is not a unique phenomenon to humans makes it difficult to identify a single cause or to establish a universal model for early modern human dispersals. For instance, paleontological studies show that numerous terrestrial mammals (e.g., several carnivores, the straight-tusked elephant, hippo, and some primates) have dispersed from Africa to Eurasia in the Plio-Pleistocene span $[34,35]$. In essence, if dispersal is a response shared by other organisms, it is likely the case that the forces that stimulated dispersals in other species may have triggered early modern human migrations out of Africa.

\section{Upper Pleistocene Human Dispersals out of Africa: A Theoretical Review}

Granted that Homo sapiens first emerged in Africa, the question of whether they left Africa in a single dispersal event or in multiple episodes has never been resolved. Within the Out-of-Africa theory, there are three principal models for human dispersals out of Africa (as reviewed by Ambrose [28]). The first one, commonly referred to as the "Strong Garden of Eden" [23], or the "African Eve" [36], model posits that after modern humans first emerged in Africa between 200-150 kya, they dispersed to other parts of the world after 100 kya and replaced all archaic hominins without any genetic admixture. The second model known as "Weak Garden of Eden" [23] asserts that anatomically modern humans evolved in a restricted area of Africa sometime after 200 kya and dispersed to separate regions around 100 kya replacing all archaic forms. According to the latter model, each human population is thought to have passed through a bottleneck in their respective destinations and then recovered after favorable conditions returned. Advocates of this model claim that around 50 kya, Later Stone Age/Upper Paleolithic (UP) cultural innovations triggered population expansion within isolated groups in Africa and Eurasia. The third dispersal model associated with the Out-of-Africa origin theory argues for multiple dispersals of early modern humans out of Africa. Originally posited by Lahr and Foley [1], this hypothesis recognizes three dispersal events in the Upper Pleistocene, and perhaps a fourth one recently proposed by Armitage [5].

\subsection{Eastward Dispersal from NE Africa to Arabia (150-} $130 \mathrm{kya}$ ). Just proposed on the basis of a recently discovered Paleolithic site (Jebel Faya) in the United Arab Emirates (UAE), dating to as old as $127 \mathrm{kya}$ [5], this event is thought to have involved human crossing of the Red Sea basin via the Strait of Bab al Mandab during the terminal phase of Marine Isotope Stage (MIS)-6, in the time range of 150-130 kya (date range by the present author). The observed lithic affinity between Jebel Faya and contemporaneous Middle Stone Age (MSA) assemblages in NE Africa suggested to researchers [5] that a direct route of migration may have existed between the two regions during low sea level events associated with MIS6 , a glacial phase dating $\sim 180-125 \mathrm{kya}$ [37]. This event is believed to have resulted in long-term human occupation of Arabia from which later expansions to other parts of Eurasia may have commenced [5]. However, whether this dispersal represents the first expansion of early modern humans out of Africa and if indeed the Jebel Faya remains were made by modern humans are unclear at this point because no characteristic hominin fossil remains have been discovered at the site yet. At best, the evidence indicates the presence of hominins in eastern Arabia with a similar lithic technology as the makers of the Middle Stone Age (MSA) tradition in Africa. A relevant evidence in connection to this route is the recent discovery of modern human fossil remains in Southern China, at the cave site of Zhirendong [38]. Dated to $>100 \mathrm{kya}$, the Zhirendong evidence signifies the presence of a successful hominin dispersal into Southeast Asia prior to 100 kya, possibly through the Bab al Mandab during MIS-6.

2.2. Northward Dispersal to Southwest Asia (130-90 kya). Before the recent discovery at Jebel Faya [5], the modern looking fossil remains associated with Middle Paleolithic (MP) industries at the Levantine cave sites of Jebel Qafzeh and Skhul, dating in the range of 130-90 kya [39-41], were considered to be the first dispersal of early modern humans from Africa [1]. As such, this event has been variously described as an "early dispersal of anatomically modern humans" by Finlayson [26] or "temporary dispersal of anatomically modern populations" by Mellars [3]. However, the identity and evolutionary significance of the Qafzeh/Skhul populations remain less well understood [42]. It is unclear whether they represent dispersed African hominins or in situ evolution from pre-existing Levantine archaic forms. Another intriguing question is what role did the Qafzeh/Skhul populations play in the Upper Pleistocene colonization of Eurasia? Perhaps, some lineages of this group specifically adapted to the Levantine environments may have served as source populations for later expansions to Europe and East Asia. Alternatively, the Qafzeh/Skhul hominins may have migrated to Arabia $[12,28]$ or to North African coastal refugia [43] in response to overpopulation or climate changes associated with MIS-4, a glacial episode dating between 75 and 60 kya [44] (Figure 1(b)). 


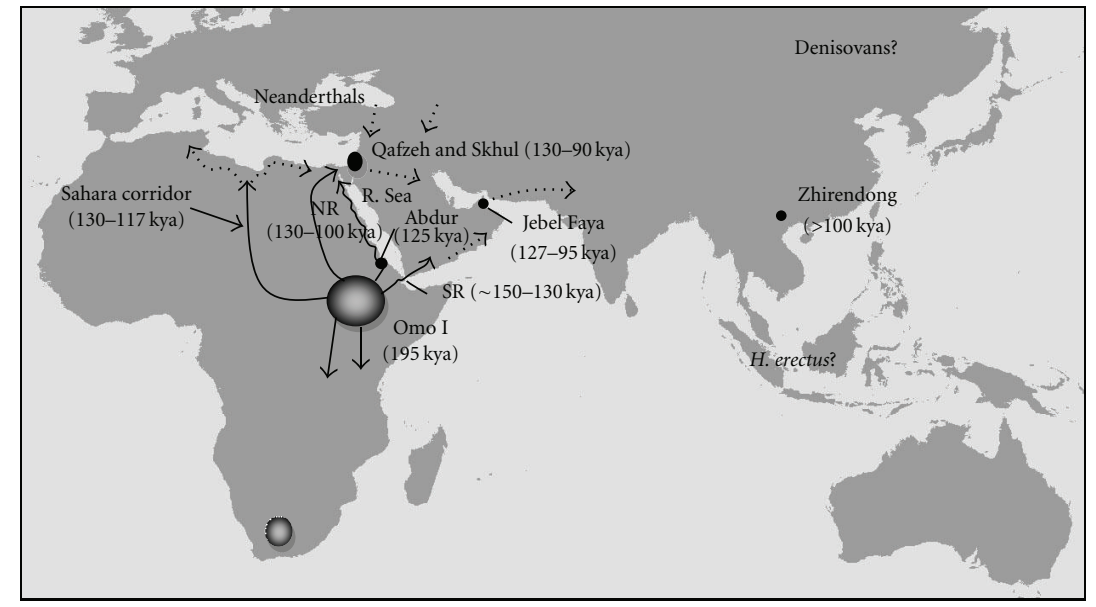

(a)

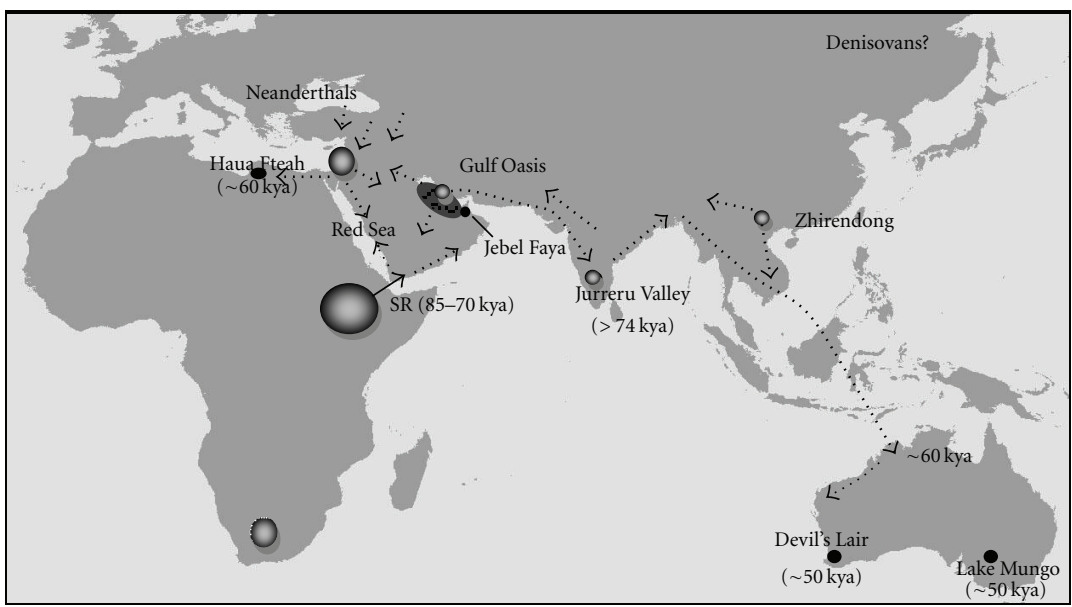

O Potential dispersal centers

- Sites associated with MSA/MP or modern human fossils

(b)

FIGURE 1: Map showing the two potential dispersal routes out of Africa and hypothetical scenarios for Upper Pleistocene hominin dispersals: (a) 150-100 kya, Homo sapiens first appeared in East Africa [19] and dispersed to Arabia, SE Asia, and Levant after 150 kya [1, 5, 38]; (b) 100-60 kya, Homo sapiens continued to expand from Arabia and from the Levant toward Southeast Asia. The reasons for these dispersals may include range expansion in response to overpopulation, competition, and climate change. Gene flow between Homo sapiens and Neanderthals may have occurred in scenario (a), and some hybrid groups may have spread to South and East Asia afterwards. Scenario (b) also depicts the timing of the purported rapid coastal dispersal from East Africa to Southeast Asia via the SR [11].

2.3. Rapid Dispersal from NE Africa to Southeast Asia (80$60 \mathrm{kya}$ ). Initially posited by Kingdon [45], advanced by Lahr and Foley [1], and lately by geneticists and archaeologists [3, $11,28,46]$, this dispersal event is thought to be responsible for the colonization of Southeast Asia and Australia around 60 kya. The key assumption behind this hypothesis is that when northward movement from East Africa into the Levant was blocked due to the expansion of the Sahara Desert during MIS-4, some East African early human groups launched an eastward expansion via the Strait of Bab al Mandab (southern Red Sea) before they successfully dispersed to Europe and western Asia. Dubbed "rapid dispersal," this event is typically associated with coastal and estuarine adaptations along the circum-Indian Ocean [4, 45, 47]. There is limited fossil and archaeological evidence supporting this event (the Zhirendong evidence [38] might fit into this route, but that belongs to earlier dispersals). The rapid dispersal event is mainly supported by mtDNA analyses of some aboriginal populations in Southeast Asia and Australia [11, 46, 48, 49]. For instance, Macaulay et al. [11] recently identified mtDNA types M21 and M22 in their Malaysian sample, and Thangaraj et al. [50] discovered M31 mtDNA type among indigenous Andamanese tribes. All these subclades stem from haplogroup $\mathrm{M}$, which is believed to have originated as a founder around $63 \mathrm{kya}$ [11] or around $65 \mathrm{kya}$ [51]. Haplogroup $\mathrm{M}$ is a direct descendant of the ancestral L3 
haplogroup, which first appeared as a founder in Africa $\sim 85$ kya $[11,51]$. The short time gap between the coalescence date of L3 (around $85 \mathrm{kya}$ ) and the arrival of its descendants in South Asia shortly afterwards ( $65 \mathrm{kya})$ suggested to researchers that the initial colonization of South and East Asia involved rapid coastal dispersal of human groups from NE Africa via the Strait of Bab al Mandab and AraboIndian littorals (Figure 3). According to Oppenheimer [46] and Macaulay et al. [11] the initial exodus into Arabia dates to roughly $85-70 \mathrm{kya}$, resulting in the initial colonization of Australia at about $60 \mathrm{kya}$, with a dispersal rate of $0.7 \mathrm{~km} / \mathrm{year}$.

2.4. Reoccupation of Southwest Asia around $50 \mathrm{kya}$. Two possible source areas have been suggested for the reoccupation of Southwest Asia by anatomically modern humans around 50 kya: (i) expansion of Later Stone Age populations from NE Africa toward the eastern Mediterranean Levant through the Nile corridor during MIS-3 (59-27 kya) warm intervals $[1,14]$, (ii) a south-north expansion from Arabian Peninsula to the Levant by human groups who previously entered the Arabian Peninsula either through the Bab al Mandab or through the Levant $[4,12,52]$. Essentially, humans who successfully occupied Southwest Asia and Europe after 50 kya are believed to have encountered Neanderthals [53]. Mellars [54] describes two phases of modern human dispersals from Southwest Asia into Europe: (i) initial occupation of southeastern Europe around $43 \mathrm{kya}$, (ii) followed by a westward movement along the Danube Valley that led to the occupation of central and southern Europe around $\sim 40$ kya.

\section{How Many Dispersal Routes?}

Currently, there are two widely accepted dispersal routes for early modern humans out of Africa [1, 11, 13, 45, 55, 56]. These are the Northern Route (NR) via the Nile-Sinai-Land Bridge and the Southern Rout (SR) through the Strait of Bab al Mandab at the southern end of the Red Sea (Figure 1). What follows below is a brief discussion of the two proposed routes and associated evidence in the context of Upper Pleistocene span.

3.1. The Northern Route. Advocates of this route propose successive dispersals of hominids and early modern humans from NE Africa into the East Mediterranean Levant via the Nile-Sinai Corridor [17, 45, 56-58] (Figure 1(a)). The NR is often linked with the arrival of the Qafzeh and Skhul hominins into Southwest Asia during MIS-5 (an interglacial phase dating $\sim 130-74$ kya) [44]. Although the presence of a dry land bridge across Sinai makes this route most accessible, considering environmental barriers associated with the aridity of the Saharan Desert, this route may have been most preferable during wetter climatic conditions [13, 59, 60]. Attempts to link the Nile Valley MP archaeology with the Levantine record do not always indicate a strong cultural connection in the Upper Pleistocene [16, 61]. After the Qafzeh and Skhul groups, no modern human presence has been detected in the Levant until after 50 kya [53]. By this time, humans had already reached Australia $[62,63]$. This long gap in the fossil record for modern human reappearance in the Levant may imply an interruption of the East African-
Levantine connection. One possible explanation for this is that the extreme cooling of the North Atlantic during MIS-4 glacial episode may have caused the Intertropical Convergence Zone and its rainfall belt to move southward closer to the Equator [25]. In this regard, Carto et al. [25, page 149] note that "the more open and arid landscape in the Sahel region may have acted as a major barrier to early $H$. sapiens dispersal at this time, restricting movement into North Africa."

Outside of the Nile Corridor, two additional dispersal corridors from East Africa into the Levant seem to have been present in the Upper Pleistocene: one to the west through central Sahara to North Africa [59] and the other to the east along the western coastal margins of the Red Sea basin [45, 65] (Figure 1(a)). Using geochemical data from wadis and by locating several fossil river channels in the Libyan Dessert, Osborne et al. [59] recently demonstrated that humid corridors existed through the central Sahara during the Last Interglacial (specifically in the time range of 130-117 kya). On the basis of this evidence and the discovery of some discrete lithic traditions in the region (specifically Aterian sites), the authors propose that the central Sahara/Libyan Desert may have served as an alternative dispersal route for early humans from central and NE Africa into the Mediterranean coast. Populations that took the central Saharan route may have ultimately dispersed to Southwest Asia along the Mediterranean coast (Figure 1). Perhaps, the Qafzeh and Skhul remains may represent an off-shoot of this dispersal route.

A less explored, but seemingly a vital region in the dispersal history of early humans is the western coastal littoral of the Red Sea basin [60,65] (Figure 1(a)). So far, there is only one well-dated Upper Pleistocene site from the entire western coastal strip of the Red Sea-the Abdur site along the Gulf of Zula, on the Eritrean coast [66]. The site produced lithic artifacts indicating MSA affinities and some bifacial tools found within an emerged coral reef terrace of the Last Interglacial period. The artifact bearing Reef Limestone at Abdur dates to $125 \pm 7$ kya [ibid.]. While there are currently some questions regarding the context of the artifacts, the chronological placement of the Abdur Reef broadly coincides with the purported northward migration of Homo sapiens into the Levant (e.g., Qafzeh and Skhul). Recently, a surface MSA assemblage has been recorded along the Eritrean Red Sea coast at a site called Asfet, about $20 \mathrm{~km}$ southwest of Abdur [67, 68]. The site is located at less than $1 \mathrm{~km}$ from the present shoreline. While the Asfet assemblage lacks an absolute age, it broadly reflects MSA adaptation. Homo sapiens that successfully adapted to the Eritrea coast in prehistoric times may have continued moving northward up to the Sinai land bridge following a coastal route. Even if there is limited archaeological evidence from the Sudanese and Egyptian coasts (largely due to inadequate research), there is no conceivable obstacle for northward dispersals of early humans along the Eritrean-Sudanese-Egyptian coastal landscapes at any point in time.

3.2. The Southern Route. This route proposes that Upper Pleistocene foragers specifically adapted to coastal habitats 


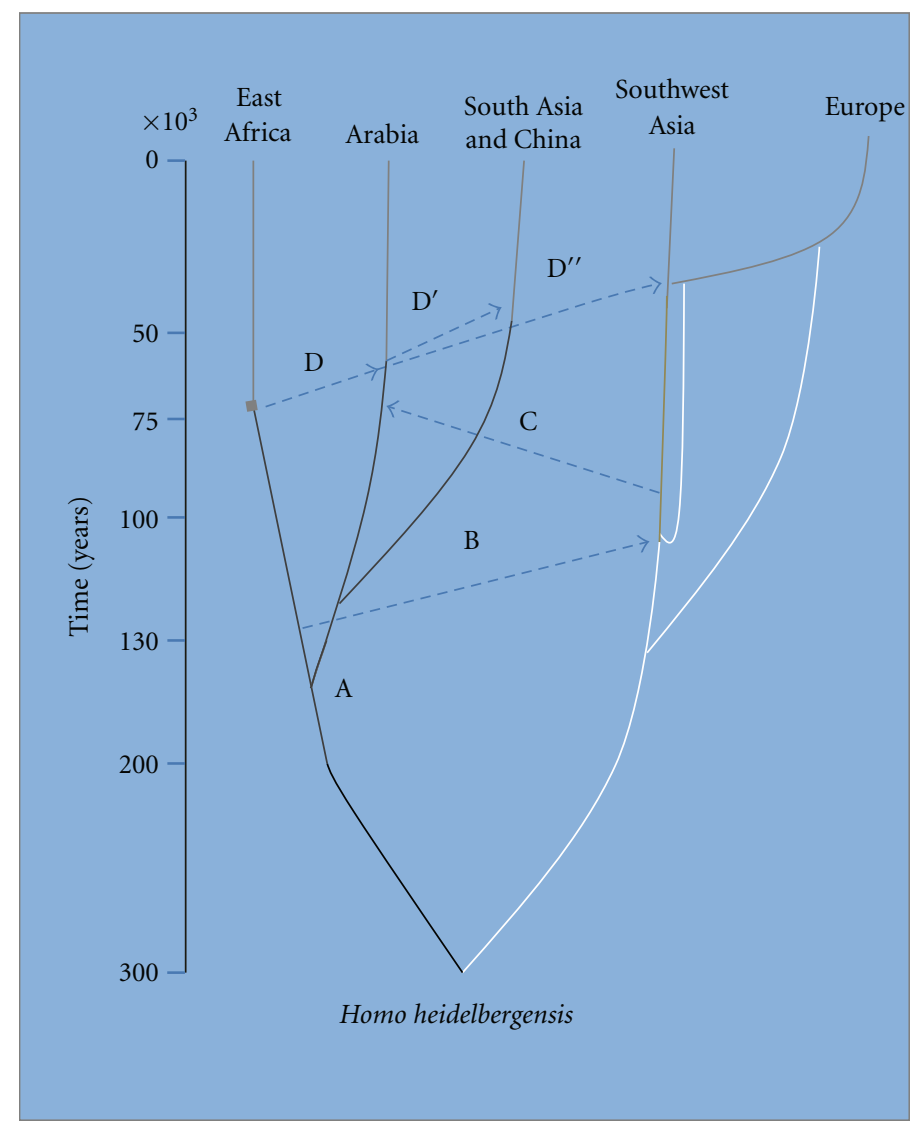

\footnotetext{
Neanderthal lineage

Archaic Homo sapiens

Homo sapiens after contact (interbreeding?) with Neanderthals in Southwest Asia (Levant)

Homo sapiens in Africa, Arabia and South Asia

Homo sapiens worldwide

A: First out of Africa dispersal of early modern humans into Arabian Peninsula via the SR, $150-130$ kya

B: Second wave of Homo sapiens dispersal out of East Africa (and Arabia?) into Southwest Asia, 130-120 kya

C: Subsequent expansion from Southwest Asia into Arabia

D: Third wave of dispersal from East Africa into Arabia, followed by eastward expansion to Southeast Asia ( $\left.\mathrm{D}^{\prime}\right)$

$\mathrm{D}^{\prime \prime}$ : Fourth expansion from Arabia, South Asia and East Africa into Southwest Asia and Europe, $\sim 60-40 \mathrm{kya}$
}

Figure 2: Potential source populations for the colonization of Eurasia in the Upper Pleistocene and a tentative reconstruction of Homo sapiens and Neanderthal relationship based on recent genetic study by Green et al. [64]. On the basis of a recent Paleolithic discovery in the United Arab Emirates [5], the first out of Africa dispersal of early modern humans may have occurred in the range of 150-130 kya. This may have stimulated successive eastward migrations of hominins up to Southeast Asia, resulting in the occupation of Zhirendong (South China) around $100 \mathrm{kya}$ [38]. The author believes that the out of Africa dispersal scenarios shown by B, D, and D" may not have resulted in replacement of the preceding inhabitants of the Levant, Arabia, and Southeast Asia (be it Neanderthals, archaic humans, or those Homo sapiens carrying Neanderthal genetic material).

in NE Africa dispersed into Southern Arabia via the Strait of Bab al Mandab during low sea level events associated with major glacial episodes $[1,4,5,11,45,46,55,60]$ (Figures 1 and 3). Once they entered southern Arabia, those human groups may have dispersed eastward using a coastal route along the Yemen-Oman littorals up to the Persian Gulf and South Asia, or they might have traveled northward up to the Levant. Most advocates of this route link it with the initial colonization of East Asia and Australia [ibid.]. The SR is mainly supported by genetic data $[11,48,50]$, discussed 


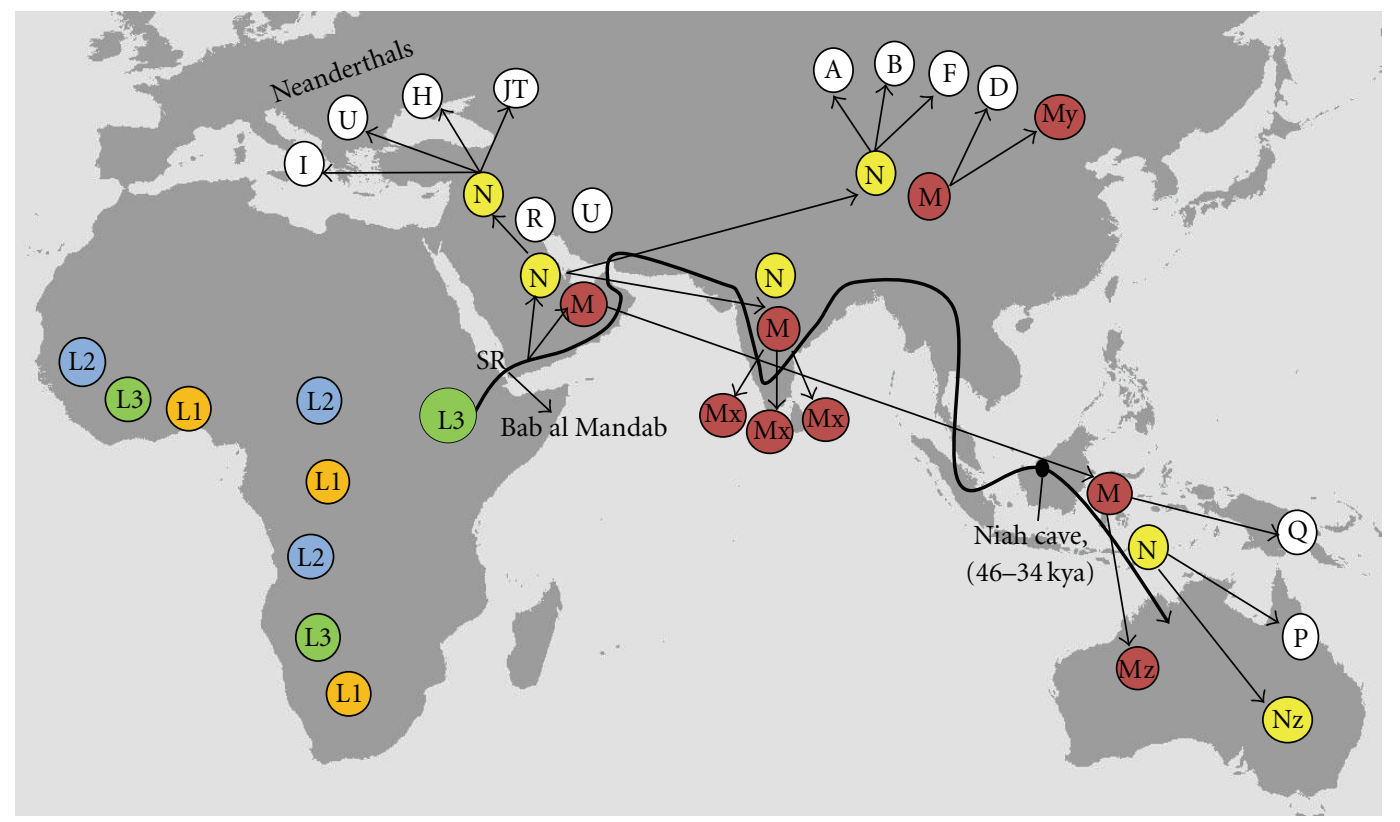

FIGURE 3: Map showing the geographic distribution of ancestral mtDNA haplogroups of modern humans in Africa and Eurasia between 60 and $30 \mathrm{kya}$, after Forster ([49, page 258], Figure 2). Note that all the ancestral haplogroups now found in Eurasia are believed to have branched from L3, which originated as a founder in eastern Africa around 85 kya [11]. The thick bold line indicates the general pathway of the southern dispersal route (SR) along the circum-Indian Ocean.

above. There are some technotypological similarities between Paleolithic sites in NE Africa and the Arabian Peninsula indicating sporadic Upper Pleistocene cultural contacts $[5,69,70]$. Generally, however, the role of the SR to long-term human occupation of Arabia and Southeast Asia remains unclear due to the lack of fossils and secured dating for the sites.

Indirect evidence suggesting episodic cultural connections between Africa and Arabia comes from a recent study concerning hamadryas baboon phylogeographic history [71, 72]. The hamadryas baboon (Papio hamadryas hamadryas) is found exclusively in East Africa and western Arabia, and is the only free-ranging nonhuman primate in Arabia [71, 73]. Previously, it has been hypothesized that hamadryas baboons colonized Arabia in the Holocene [73]. However, a recent study of mtDNA variation among Saudi Arabian and East African (Eritrean) hamadryas populations shows that these baboons did not colonize Arabia in the recent past nor did they use a northerly route via the Sinai land bridge to enter Arabia Peninsula. The data suggests that hamadryas baboons reached Arabia via temporary land bridges formed during glacial maxima along the Strait of Bab al Mandab. Given the fact that the most recent common ancestor of hamadryas baboons lived in Arabia around 85-119 kya [ibid.], the likely time for hamadryas entrance to the Peninsula has been estimated $\sim 86-220$ kya [ibid.]. If such a recent dispersal of hamadryas baboons was possible across the Red Sea (Strait of Bab al Mandab), this route must have been equally accessible to early modern humans during low sea level events in the Upper Pleistocene, such as MIS 6, 4, and 2
[74]. There is no evidence for a prolonged interruption of water exchange between the Red Sea and the Indian Ocean throughout the last 470 kya years [75]. Therefore, any faunal or hominin exchange along this route should have occurred during temporary land bridges. Otherwise, human migration across the Red Sea during humid periods must have involved crossing a body of water using floating objects or by swimming, which is difficult to prove archaeologically.

\section{Single or Multiple Centers of Upper Pleistocene Human Dispersals? Archaeological and Genetic Perspectives}

4.1. Archaeological Perspectives. The archaeological assessment here focuses on the general aspects of MSA/MP lithic industries from NE Africa, the Levant, and Arabia Peninsula. The degree to which lithic techno-typology could be informative about hominin dispersal history requires some clarification. In the older literature, it has been suggested that typological similarities signal population movement, while technological parallels may reflect similar adaptive behavior between comparative regions [76, 77]. But, such criteria may not work consistently across broad geographic areas because lithic technology is contingent upon the local habitats, ecological factors (raw material), the intended use of the artifacts, and idiosyncratic choices of the knappers [78]. For instance, when we look at the cultural traces found in association with the modern looking fossil remains in Australia, they do not show any affinity with Middle or 
Later Stone Age (LSA) traditions of Africa or Europe [4], signifying that there is not always direct association between lithic traditions and specific hominin groups.

By and large, the Upper Pleistocene human dispersals out of Africa correlate with the MSA tradition in Africa or MP in Eurasia, broadly dated between 250 and 40 kya $[8,29,81]$. The MSA is best characterized by the use of Levallois technique and point production [29, 82]. The distinctive features of the Levallois technique are striking platform preparation and predetermination of the resulting flakes [83]. The relative paucity of scrapers and the presence of a large number of foliate points distinguish the African MSA from the MP of Eurasia [29]. Paleolithic scholars working in Africa identify numerous behavioral innovations associated with the MSA cultural entity. These include (i) technological standardization in producing diverse point styles, (ii) abstract thinking and symbolic behavior manifested in the use of ochre, geometric engraving design, and use of body adornments, (iii) planning and extensive alliance networks reflected in long distance raw material transportation, and (iv) use of aquatic resources [29, 84-86]. These behavioral complexes are thought to have stimulated economic diversification and dispersals within and out of Africa in the Upper Pleistocene [ibid.]. Of these, projectile technology is considered to be an important innovation that enabled modern humans to broaden their spatial and dietary niches [29, 30, 87, 88].

As stated above, East Africa has yielded the oldest modern looking fossil hominins [6, 7], and the earliest MSA industries characterized by regionally diversified point technology produced using façonnage technique, and a large range of flake tools from Levallois and blade cores $[8,20,29,82,89]$. Two main technocomplexes: the "Nubian" and "Lower Nile Valley" characterize the MP tradition in the Nile Valley area. The relationship between these complexes and those of the Levantine MP and East African MSA remains poorly understood $[16,17,78]$. In general, the façonnage technique distinguishes the NE African MSA industries from the Levantine and the Nile Valley MP assemblages. Façonnage method involves tool production from a core by invasive and usually bifacial flaking [90]. Middle Paleolithic assemblages with façonnage technology have been recorded in some MP sites in Arabia [5, 15], but not from the western region-the area expected to receive the most east African MSA cultural influence. The lack of strong technological similarity between east Africa and western Arabia has become an obstacle for researchers trying to glean evidence for early human contacts via the Strait of Bab al Mandab. In this regard, Marks [69, page 302] writes "given the proximity between the western Yemeni littoral and the eastern coast of East Africa, it is strange that no clearly African or even African related assemblages have been found."

The role of the Levant in clarifying early human migration out of Africa has long been recognized [16, 58, 91]. Indeed, the region has produced rich paleontological and paleoanthropological evidence that should be informative about hominin migration history to and from Africa [9295]. Initially, the Levantine record was vital in supporting the gradual emergence of modern humans out of the
Neanderthal line [96]. However, with recent improvements in dating techniques $[97,98]$, it has become evident that Neanderthals and early modern humans in the Levant were contemporaneous, both manipulating Levallois technique, sharing similar habitats [99] and possibly interbreeding [64]. The MP archaeological complexes in the Levant are collectively referred to as the Levantine Mousterian, which are believed to have evolved from local Late Acheulian and Mugharan industries that were mainly confined to the northern Levant [16, 100-102]. Laminar and recurrent Levallois techniques for the production of blades and triangular to subtriangular flakes characterize the Levantine assemblages [ibid.]. They are mainly distinguished from the African MSA assemblages by the absence of bifacial/façonnage reduction. One problem with the Levantine MP is that at least two species of Upper Pleistocene Homo had been associated with it. For instance, the Levallois technique, which is one of the defining features of MSA/MP assemblages, was produced by Neanderthals and early modern humans in this region [99]. This makes it difficult to discern local technological innovations from those brought by the dispersing humans.

Although Arabia had a marginal mention in human evolutionary discussions in the past, past and recent research activities in the region have produced a plethora of prehistoric data spanning from the Lower Palaeolithic up to the Neolithic times ([103] and references therein). When it comes to the MP record of the region, Marks [69] identifies three variants corresponding to three ecogeographic zones: (i) the western and south-western regions mainly characterized by convergent Levallois and blade technology, (ii) the South (mainly Oman), featuring unidirectional hard hammer, large blade production from cores with flat platform, and the production of bifacial foliates using façonnage, (iii) sites on the eastern region, exhibiting a number of different reduction strategies, such as façonnage to produce both small handaxes and foliates, blade production from multiple platform and unidirectional cores, and flake production from crude Levallois and centripetal radial strategy. Despite the existence of abundant Paleolithic sites in Arabia, the findings lack reliable dates and hominin fossil association. Some recently discovered MP industries on the western and southern parts of Arabia contain characteristic Levantine technological features, such as heavy emphasis on unidirectional Levallois technique for the production of convergent points and blades $[69,104,105]$. The Levantinerelated Levallois method is poorly represented in Oman and in those areas east of the Rub'al Khali Desert; instead the sites there display a mosaic of local technological developments and some East African MSA affinities [69, 104].

Somewhat appealing evidence concerning Upper Pleistocene cultural connections between NE Africa and the Arabian Peninsula comes from the recently excavated MP assemblage at the site of Jebel Faya 1, UAE [5]. Radiometrically dated to $\sim 127-95 \mathrm{kya}$, one stratified assemblage at the site (Assemblage $\mathrm{C}$ ) contains both small handaxes and foliate points produced by façonnage technology, revealing close technological similarity with NE African MSA industries $[5,69]$. Two younger assemblages from the site (A and B) indicate no apparent technotypological affinity with 
the Levantine, NE African, or other assemblages in the Arabian Peninsula [69, page 305]. Interestingly, a surface MSA assemblage with similar took kit to that of Jebel Faya Assemblage $\mathrm{C}$ has recently been documented on the Eritrean Red Sea coast, at a site called Asfet [67]. Although the Asfet material lacks an absolute date, the presence of bifacial foliates and small handaxes in association with various kinds of blades/flakes produced by Levallois and parallel method signifies similar adaptive behavior and/or culture-historical relationship between the inhabitants of Asfet and Jebel Faya. The author hopes to undertake detailed comparative investigation of the two assemblages in the near future.

Overall, the Arabian MP lithic entities, especially those on the western margin, do not show strong affinity with their east African MSA counterparts. The findings from the western side of the Peninsula suggest stronger cultural connection with the Levant. However, whether this is due to population diffusion from the Levant into western Arabia and vice versa, or due to adaptation to similar environmental settings, remains unclear. It is worth noting that the western side of Arabia and southern Levant exhibit similar environments, featuring coastal plains and high plateaus [69]. Thus, the vast strip of land stretching from southern Levant up to southwestern Arabia may have served as an ecological refugium and a conduit of continuous prehistoric human contacts $[69,106]$.

On the basis of new paleoenvironmental, archaeological, and genetic evidence from the Arabian Peninsula and southern Iran, Rose [12] has recently formulated an enticing model dubbed the "Gulf Oasis," in which he proposes "early modern humans were able to survive periodic hyperarid oscillations by contracting into environmental refugia around the coastal margins of the peninsula" [ibid., page 849]. Based on this model, the author hypothesizes that the Persian Gulf may have been a source area for Upper Pleistocene human diffusion to East Asia, to Southwest Asia, and possibly to East Africa. At the center of the model lies the assumption that sea level decline during arid periods (associated with glacial episodes) enhanced the discharge of fresh water from terrestrial aquifers along the continental shelves, thereby creating favorable habitats along the gulf basin when much of the hinterlands were dry [107]. The presence of subterranean freshwater upwells beneath the Persian Gulf has been confirmed by geological studies (see detailed literature review on this topic in Rose 2010 [12]). While the Gulf Oasis model sets a plausible scenario for Upper Pleistocene hominin diffusion from Arabia, it can be critiqued based on the lack of evidence (so far) for in situ origin of any of the two ancestral mtDNA - haplogroups $\mathrm{M}$ and N-in Arabia [108, 109].

Outside of Arabia to the east, several MP sites have been documented in India $[110,111]$. However, the culturehistorical relationship of the region to the African continent has not been systematically investigated yet. An ongoing archaeological investigation around the Jurreru Valley (India) has documented cultural traces in a deposit predating the Toba eruption $\sim 74 \mathrm{kya}$, but the exact cultural context of the artifacts has yet to be determined [112]. Recently, Mellars [3,4] reported the presence of a strong resemblance between Later Stone Age (LSA) assemblages in India and Sri Lanka (dated to $\sim 34 \mathrm{kya}$ ) and some derived MSA tools and symbolic objects from sub-Saharan Africa (e.g., crescents, geometric engravings, and shell beads). According to Mellars [ibid.], these similarities imply a rapid wave of modern human dispersal from eastern Africa carrying diverse cultural innovations, thereby supporting the "single dispersal" hypothesis for Upper Pleistocene human colonization of South and East Asia. In this regard, Mellars suggests that MSA behavioral innovations that first appeared in southern and eastern Africa played a key role in fueling human dispersals into Eurasia. Although Mellars' assertions appear plausible, the apparent lack of such artifacts at other (relatively older) fossil sites in the region, such as Niah Cave [113], and Lake Mungo [114], calls into question the role of the purported cultural novelties in Africa in fueling human dispersals into Eurasia. After all, it is not clear if, indeed, the Indian LSA sites were derived from the rapid dispersal event discussed above. Perhaps, some of the fossil and archaeological sites in this region may represent local evolution from preceding modern human settlements, such as the one reported from Zhirendong [38].

4.2. Genetic Perspectives. Genetic studies of modern human populations show that the most recent common ancestor of all humans - referred to as the "Mitochondrial Eve" or "Real Eve"-lived in Africa between 200 and 150 kya [21, 115117]. The mitochondrial deoxyribonucleic acid (mtDNA) has been particularly useful for studies of human evolution and prehistoric migrations $[49,118,119]$. Its high copy number, maternal inheritance, lack of recombination, and high mutation rate have made mtDNA an important molecule in tracing human descent back to several thousand years [118]. The basic premise of the genetic approach is that similarities in mtDNA are due to shared descent. Harpending et al. [117] described the main tenets of the genetic approach to human evolutionary studies as follows: (i) all humans originated from a population that was effectively a separate species for at least 1 or 2 million years, (ii) human genetic variation is relatively low indicating that the number of effective population size was roughly on the order of 10,000 breeding individuals throughout the Middle to Upper Pleistocene or 10,000-20,000 throughout the Pleistocene [120], (iii) a specific population ancestral to modern humans underwent demographic expansion in Africa, subsequently occupying Eurasia and the New World, and (iv) the best available estimates of mtDNA mutation rates imply that the expansion occurred between 100,000 and 50,000 kya.

Mitochondrial DNA variation among present-day African lineages suggests that Africa saw a "remarkable expansion" of two mtDNA haplogroups, namely, L2 and L3, between 85 and 55 kya $[11,49,51]$. Subsequently, a small population carrying L3 haplotype is thought to have left East Africa via the SR $\sim 70-65$ kya (Figure 3), giving rise to two founding sister haplogroups outside of Africa, namely, $M$ and $N$ [49]. This means that all contemporary non-African humans have descended from either $\mathrm{M}$ or $\mathrm{N}$ haplogroups, both derived from the ancestral African haplogroup L3. The age of haplogroup L3 is estimated to be $\sim 85 \mathrm{kya}$ and that of 
haplogroups $\mathrm{M}$ and $\mathrm{N} \sim 63 \mathrm{kya}[11,121]$. The two descendant haplogroups have somewhat distinct geographic distribution with the $\mathrm{M}$ lineages mainly concentrated among eastern African, South Arabian, Indian, and Southeast Asian populations, whereas descendants of haplogroup $\mathrm{N}$ are mainly found in western and central Eurasia [49, 122]. Due to its presumed older age and widespread presence in eastern Africa and southeast Asia, haplogroup M or its African type clade M1 has been considered a vital genetic marker for tracking Upper Pleistocene human dispersals [123]. Moreover, the absence of haplogroup M clades among Southwest Asian populations has suggested to some researchers that the Arabian Peninsula may have served as the sole conduit of human dispersals out of Africa, thus lending support to the SR hypothesis $[123,124]$. A recent genetic study by Macaulay et al. [11] and Thangaraj et al. [50] discovered ancestral lineages of macrohaplogroup $M$ in some native populations of Malaysian Peninsula and Andaman Islands, respectively (discussed above). From this, the authors propose a single wave of early modern human dispersal from East Africa to Southeast Asia via a southern coastal route sometime between 65 and 60 kya. Despite the emerging rebuttals (see below), the authors claim that the southern coastal route was the only successful migration that resulted in a long-term occupation of South and East Asia.

4.3. Recent Critiques and Alternative Views. The most viable critique to the single rapid dispersal hypothesis comes from four concurrent lines of evidence: (i) a growing body of recent genetic evidence that shows in situ origin of haplogroups $\mathrm{M}$ in South Asia [50, 125-129], (ii) the recent discoveries of a well-stratified MSA/MP assemblage in Eastern Arabia dating to $85 \mathrm{kya}[69,130]$ and modern human fossil remains from Zhirendong cave in southern China dating to $>100$ kya [38], (iii) a recent multivariate analysis of morphometric data that shows close genetic affinity between early modern humans from the Levant and terminal Pleistocene/early Holocene fossils from Australasia [131], and (iv) a more recent genetic study on the Neanderthal nuclear genome that shows that Neanderthals shared more genetic variants with present-day humans in Eurasia than with present-day humans in sub-Saharan Africa [64].

By examining genetic diversity among Asian and North African extant populations, Olivieri et al. [125] and González et al. [126] propose an Asian origin of haplogroup $M$ and its back migration via the Sinai land bridge into Africa sometime between 45 and 40 kya. In this regard, González et al. [ibid., page 223] write, "The coalescence age of the African haplogroup M1 is younger than those for other $\mathrm{M}$ Asiatic clades. In contradiction to the hypothesis of an eastern Africa origin for modern human expansions out of Africa, the most ancestral M1 lineages have been found in Northwest Africa and in the Near East, instead of in East Africa." Rowold et al. [132] provide additional evidence for back migration of Upper Paleolithic populations through the Sinai land bridge. The possibility of back migration from Asia to Africa has also been confirmed by other genetic studies on human Y-chromosome haplotypes [128, 129]. Further indirect evidence for an Asian origin of haplogroup
M comes from recent studies on the genetic diversity of the Arabian populations, which show stronger influence of South Asian $\mathrm{N}$ and $\mathrm{M}$ haplogroups in the founding lineages of the Arabian mtDNA [109, 122, 127]. Interestingly, much of the existing genetic ties between NE Africa and Arabia have been attributed to historic contacts between Afro-Arabian kingdoms [122]. In light of the growing genetic data in favor of an Asian origin of haplogroup M (one of the two founding mtDNA haplogroups for all modern humans outside of Africa), there appears to have been an Asiatic locus/loci of Upper Pleistocene human expansions.

As discussed above, a diagnostic MSA/MP assemblage (Assemblage C) has recently been identified at the site of Jebel Faya, UAE [5]. Its date falls in the range of MIS-5e (127-95 kya) and is considered to be the oldest evidence of modern human dispersals out of Africa prior to the purported rapid coastal migration [11]. The period between 100 and 50 kya is poorly represented by fossil hominins and well-dated Paleolithic assemblages outside of Africa. In this regard, some scholars $[3,26,46]$ hypothesize that the initial migration of modern humans from Africa (represented by Qafzeh and Skhul fossils) did not result in a widespread human expansion outside the Levant. The identity and contribution of the Jebel Faya humans to the Upper Pleistocene colonization of Eurasia is unknown, but given its pivotal location en route between NE Africa and South Asia, the evidence is of a paramount significance in assessing the timing and the geographic contexts of early modern human dispersals. Early modern humans that originated in Africa around 190 kya may have subsequently migrated to Arabian Peninsula during MIS-6 through the SR. From Arabia, some modern human groups may have launched an eastward migration along the Arabian-Iranian-Indian coastal refugia reaching southern China around 100 kya [38]. Subsequently, hominins specifically adapted to those putative refugia may have served as founder populations for later human expansions into East Asia and Australia (Figure 1).

The Australian genetic and fossil records have been important in calibrating Upper Pleistocene human dispersal events at various points in time $[1,48,114,131,133]$. The oldest archaeological traces of early modern humans in Australia have been dated to $\sim 50 \mathrm{kya}$ at the sites of Lake Mungo [114] and Devil's Lair [63]. Geneticists extend the arrival of humans in Australia up to 60 kya or slightly earlier [11,46, 133]. A number of geneticists also claim close mtDNA affinity between East Africans and Australasian aboriginals, in so doing they propose a single wave of human expansion from eastern Africa after 85 kya [ibid.]. Nonetheless, a recent multivariate analysis of cranial morphometric data has shown close genetic affinity between early modern humans from the Levant (Qafzeh and Skhul) and terminal Pleistocene/early Holocene fossils from Australasia [131]. According to the study, an early dispersal ( 100-76 kya) from Africa by a more ancient lineage of modern humans may have contributed to the initial colonization of Australasia [ibid., page 814], thereby suggesting a direct contribution of the Qafzeh and Skhul groups in peopling Eurasia during the Upper Pleistocene. 
The fourth source of disagreement with the single dispersal hypothesis comes from a recent genetic study on the Neanderthal genome, which shows that Neanderthals shared more genetic variants with present-day humans in Eurasia than with present-day humans in sub-Saharan Africa [64]. From this, the authors of the study conclude that "gene flow from Neanderthals into the ancestors of non-Africans occurred before the divergence of Eurasian groups from each other" [ibid., page 710]. Although it is too early to speculate much about this finding, the study offers a plausible scenario for deep genetic roots in Eurasia and hints that the initial dispersal of modern humans into Southwest Asia associated with the Qafzeh and Skhul groups was not a failed one (Figures 1 and 2). Perhaps, that expansion may have ultimately resulted in early modern human and Neanderthal contacts/interbreeding in Southwest Asia. Modern human groups with Neanderthal genetic material may have survived in Southwest Asia throughout the succeeding millennia giving rise to some ancestors of present-day Europeans and Asians (Figure 2). In this regard, Rídl [134] proposes two possible scenarios as to why parts of the Neanderthal genome may have been preserved in present-day Europeans and Asians but not in Africans:

...the first explanation is that there was an ancient polymorphism among archaic populations in Africa. In that case, Neanderthals and all humans outside of Africa would stem from the same population whose other descendants have become lost (or minor) in Africa. The second and probably more parsimonious scenario involves interbreeding between Neanderthals and modern humans. This would mean that there was a single population of modern humans whose ancestors met (and mated) Neanderthals somewhere in southwest Asia and whose descendants subsequently colonized the rest of the world outside of Africa [page 873].

In a nutshell, the recent study on the Neanderthal genome joins the other lines of evidence discussed above $[5,50$, $125-129,131$ ] in suggesting that several dispersals or multiple loci of human expansions (the Levant included) may have existed outside of Africa during the Upper Pleistocene.

\section{Paleoclimate, Coastal Environments, and Human Dispersals}

The effects of past climate changes on biogeographic distribution, extinction, and migration of species have long been recognized $[26,49,135,136]$. In his recent review of the biogeography and evolution of the genus Homo, Finlayson [26, page 457] categorically argued that "climatedriven ecological change has been, as with many other taxa, the driving force in the geographic range dynamics of the genus Homo." Similarly, Forster [49, page 255] notes that "most of our own mtDNA studies during the past decade strongly imply a major role for paleoclimate in determining conditions for prehistoric migrations and demographic expansions." The period associated with the origin and dispersals of early humans (200-50 kya) saw recurrent glacial events that caused prolonged sea level decline (Figure 4). Two of such events are MIS-6 and 4, dating in the range of 180-125 and 75-60 kya, respectively, [37, 44]. Potential adaptive responses to climatic aridity may include migration, population fragmentation, and subsistence on low-rank resources.

On the basis of global climate model simulation, Carto et al. [25, page 140] recently reported that "Heinrich events which occurred episodically throughout the last glacial cycle, led to abrupt changes in climate that may have rendered large parts of North, East, and West Africa unsuitable for hominin occupation, thus compelling early Homo sapiens to migrate out of Africa." Heinrich events are short cold periods that occur when freshwater fluxes associated with ice sheet surges into the North Atlantic caused southward shift of the Intertropical Convergence Zone over Africa [25, page 139]. During such cold times, human movements may have been restricted to coastal environments. Rose [104] in formulating his "Arabian Corridor Migration Model," linked human dispersals into Arabia with the expansion of the savanna ecogeographic zone during wet (pluvial) episodes. Ideally, human dispersals out of Africa may have occurred during cold and warm conditions in response to population expansion, increasing competition and some autocatalytic factors whereby the discovery of new attractive areas led to the expectation of more vacant habitats [137].

There is increasing evidence showing that coastal habitats played an important role in the course of human evolution as stable refugia and corridors of biogeographic expansion $[45,66,138-140]$. Decades ago, Sauer ([140] page 311-112) proposed that "the dispersal of early man took place most readily by following along the seashore; coastwise there was a scarcely a barrier to the spread of early man through tropical and subtropical latitudes." Sauer's idea was later advanced by an Africanist biogeographer Jonathan Kingdon, who related early human migration out of Africa to mammalian dispersal patterns from East Africa to Southeast Asia [45]. Kingdon proposed a circum-Indian Ocean coastal dispersal for the colonization of Southeast Asia and Australia by early humans, arguing that the main prerequisites to human dispersal out of Africa were adaptation to coastal environments and raft building technology. Recently, Bulbeck [47] upon adopting Kingdon's view hypothesized an estuarine based model for the eastward dispersal of early humans from Africa to Southeast Asia up to Australia. Accordingly, adaptation to resource rich estuaries is thought to be the "main impetus for the migratory movement" of Homo sapiens toward Southeast Asia [ibid., page 315]. The Indian Ocean coastal rims may have been particularly attractive to mobile foragers due to the availability of a mix of estuarine, coastal, and terrestrial resources. Using a Geographic Information System generated model, Field and Lahr [60, page 1] recently proposed that, "rapid dispersals along coastlines and river valleys would have occurred upon the initial expansion out of Africa, but slowed as populations expanded demographically into South Asia and the Sunda Shelf."

During glacial times, a vast amount of freshwater is locked up in the polar ice sheets, causing sea levels to 


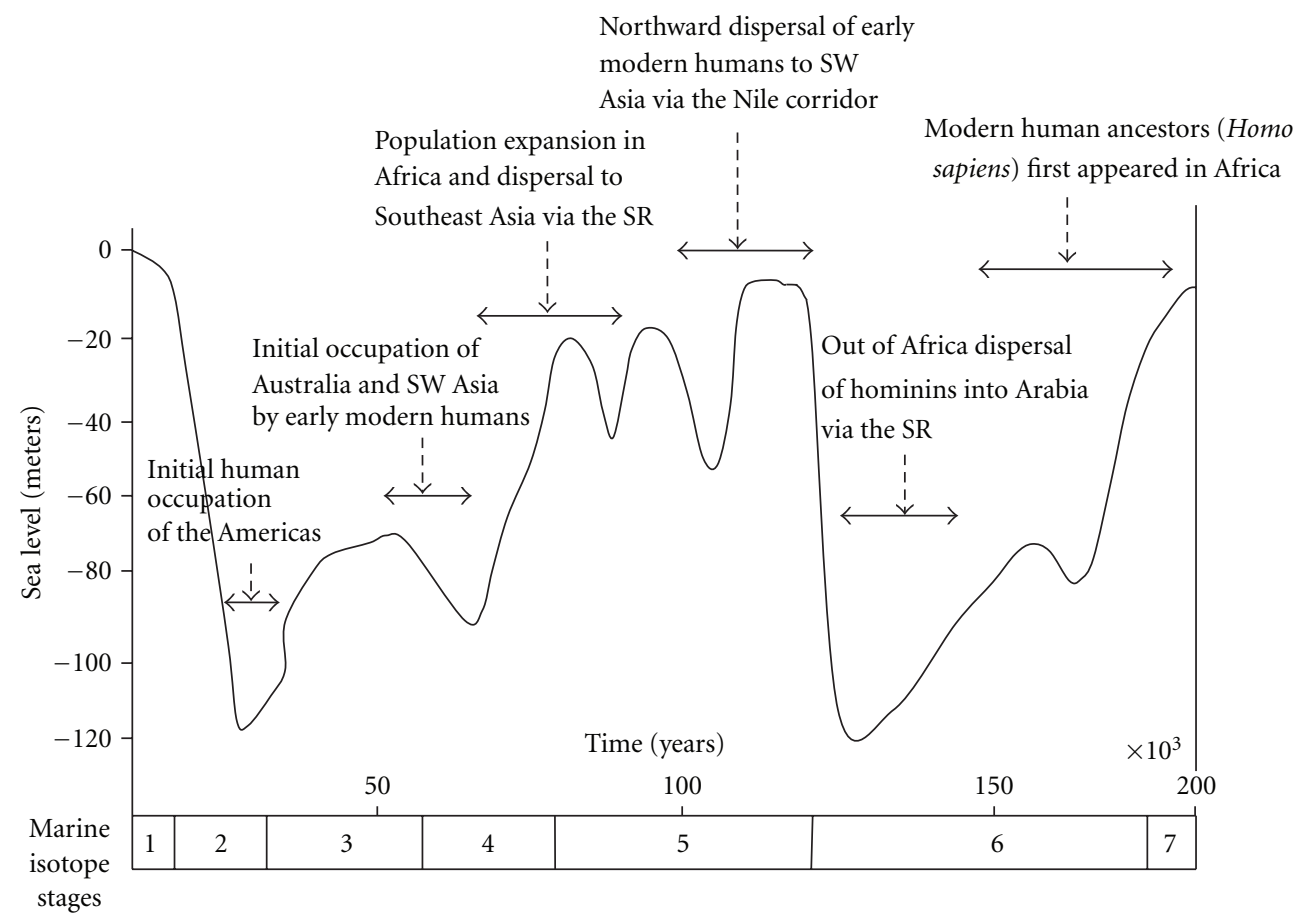

Figure 4: Sea level changes and early modern human dispersal events in the Upper Pleistocene [3, 46, 79]. Sea level chart redrawn from Siddall et al. ([80, page 143], Figure 2).

drop as low as $130 \mathrm{~m}$ below their present height $[80,141]$. Such events may have created vast coastal territories for early humans to exploit. Coastal margins may have been particularly attractive when sea levels were low due to the formation of freshwater springs along the newly exposed coastal gradients [107]. According to the Coastal Oasis model proposed by Faure et al. [ibid.], the flow of groundwater along the coastal gradients increases when sea level drops during major Ice Ages. Sea level is at a high interglacial position now, thus relics of coastal adaptation associated with Ice Age coastal oases may be found underwater now. Human movement along coastal margins can be faster and safer because once humans developed the strategy to exploit one coastal territory, there is little need to device new technology to exploit another coastal habitat $[47,79,140]$. Despite all these potentially viable scenarios, there is limited coastal archaeological evidence from Southeast Asia. This could be due to successive sea level transgressions that may have inundated most prehistoric sites formed near coastal landscapes. It is worth noting that a few sites that suggest human use of tropical refugia have been documented in East Asia $[47,113]$.

A topic of particular interest related to this discussion is the occupation of Australia by early modern humans as early as 50 kya or slightly earlier $[63,114,142]$. The occupation of Australia is intriguing because it did not only involve coastal movement, but crossing a vast body of water possibly using floating rafts [143]. Lake Mungo, from where the oldest fossil remains of early modern humans have been recovered [144], is located about $2700 \mathrm{~km}$ from the northern coast of Australia, which is the likely entry point for early humans into Australia. The site dates to $~ 50$ kya [114]. The accepted model is that humans first travelled along the western coastal rims all the way up to the southern tip of Australia before reaching Lake Mungo [144]. Another similar scenario is human colonization of North America during the terminal Pleistocene, which involved a rapid dispersal to South America along the Pacific coast before occupying the interior habitats [145]. In both cases, humans embarked on coastal colonization prior to moving into the interior landscapes.

The earliest well-dated evidence for coastal adaptation by anatomically modern humans has been reported from South Africa, at the site of Pinnacle Point dating to 164 kya [86, 146]. South Africa has also produced rich coastal evidence for the time range 120-70 kya [147-151]. The presence of a plethora of later Pleistocene coastal sites in Southern Africa may signify that the region served as an important refugium during glacial times from where later human expansions to the rest of Africa commenced when favorable conditions prevailed $[146,147]$. The Abdur site on the Eritrean coast $(\sim 125 \mathrm{kya})$ offers the only evidence for Upper Pleistocene human coastal adaption in NE Africa [66]. Moreover, a recent study concerning the evolutionary history of the Giant Clam (Tridacna costata) along the Sinai Peninsula (northern Red Sea) reported a sharp decline in proportion and shell size in this species starting at $\sim 130$ kya [152]. This is interpreted as "the earliest depletion reported so far of a shallow-water megafaunal invertebrate associated with the dispersal of anatomically modern humans out of Africa into the Red Sea and adjacent regions 110,000 to 90,000 years ago" [ibid., page 2]. Although there is limited coastal evidence from eastern 
Africa (largely due to lack of sustained research), any direct hominin contacts between East Africa and Arabian Peninsula must have involved coastal adaptation, and possibly raft building technology.

\section{Summary and Conclusions}

In spite of continued research progress in all fields of paleoanthropology, the present generation is particularly confronted with a complex set of long accumulated conflicting views about the origin and dispersal history of early modern humans. This paper is an attempt to shed some light on the current state of the scientific debate on Upper Pleistocene (128-12 kya) human dispersals out of Africa and their successive colonization of Eurasia. Researchers have often relied on archaeological, genetic, and fossil data to examine patterns of early human dispersals $[11,13,15,131]$. However, these approaches have continued to suffer from a lack of consistent evidence from the contributing regions, such as the Nile Valley, the Levant, and the Arabian Peninsula $[12,16,153]$. Some, but not all archaeological and genetic publications reviewed here, hint at multiple loci of Upper Pleistocene human expansions outside of Africa. The main conclusions of the current paper are succinctly presented in Figures 1 and 2.

The existing MSA/MP archaeological record does not show strong technotypological parallels between NE Africa and the two adjacent regions-Arabia and the Levant. The Levantine MP industries have local origin from the late Acheulian tradition, and they indicate minimum incursions of Afro-Arabian technologies into the region. Scholars working in the Arabian Peninsula identify regional lithic varieties, some possessing local origin, while few others demonstrating close ties to MSA industries in the neighboring regions $[69,104,105]$. Although broad technotypological similarities have been recognized among some MP/MSA sites in Arabia (e.g., Jebel Faya in the UAE, Bir Khasfa, and Jabal Ardif 3 in Oman) and NE Africa (e.g., Station One in Sudan, Kulkuletti and Porc Epic in Ehtiopia) [13, 69, 154, 155], overall, the existing evidence hints at rather weak cultural contacts between the two regions (assuming that lack of lithic similarity denotes absence of cultural exchange, although that may not be always the case). The recently reported Assemblage $\mathrm{C}$ from Jebel Faya remains the prima facie evidence for potential cultural connections between Arabia and NE Africa. However, in the absence of corroborative evidence from the western and southwestern margins of Arabia (areas closer to Africa), it is difficult to ascertain the origin and migration routes for the makers of the Jebel Faya Industry. Much of the existing MP evidence from the western and southern Arabia shows closer affinity with the Levantine MP than with East African MSA [69]. From the recently formulated "Gulf Oasis" model [12], human presence in the Arabian peninsula appears to have persisted since the onset of the Last Interglacial (MIS-5) by relying on the expanding grassland habitat during wet phases and on environmental refugia during dry conditions [12]. The present author is in agreement with Rose's assertion that the Arabian Peninsula may have served as a potential center for Upper Pleistocene human expansion to East Asia, to Southwest Asia or back to Africa.

The reviewed literature hints at two modes of early modern human colonization of Eurasia in the Upper Pleistocene: (i) from multiple Homo sapiens source populations that had entered Arabia, South Asia, and the Levant prior to and soon after the onset of the Last Interglacial (MIS-5), (ii) from a rapid dispersal out of East Africa via the Southern Route (across the Red Sea basin) during MIS-4. A wealth of genetic data accumulating from South and Southwest Asia [50, 64, 122, 125-127] supports in situ origin of one of the ancestral mtDNA lineages-haplogroup M in Asia, signifying an Asiatic source populations for the colonization of Eurasia in the Upper Pleistocene. This view contrasts with the "single dispersal" hypothesis $[11,50]$, which posits that the founding lineages ( $\mathrm{M}$ and $\mathrm{N}$ lineages) of South and East Asian populations were products of a single wave of modern human expansion from eastern Africa during MIS4, dating to 74-60 kya. In conclusion, two potential routes of human migration out of Africa (the Northern and Southern Routes) can be recognized, but there does not appear to be a clear consensus on the exact timing and source populations for Upper Pleistocene human colonization of Eurasia: the genetic data suggesting multiple source populations outside of Africa and the archaeological evidence indicating weak cultural relationships among those regions presumed to be key players in human dispersals (NE Africa, Arabia, and the Levant).

\section{Acknowledgments}

Thanks are due to Richard Leakey and Lawrence Martine for providing the author with a postdoctoral fellowship in the Turkana Basin Institute which enabled him to undertake this work. The author expresses his gratitude to Parth Chuan for inviting him to submit this paper to this special issue of International Journal of Evolutionary Biology. For review and editorial assistance, the author is particularly grateful to Darren Curnoe, an anonymous reviewer, Karen Baab, and John Shea. Several publications $[5,12,64,69,131]$ helped the author to streamline the contents of the paper, and he is thankful to the authors for their inspiring ideas and reports.

\section{References}

[1] M. M. Lahr and R. Foley, "Multiple dispersals and modern human origins," Evolutionary Anthropology, vol. 3, no. 2, pp. 48-60, 1994.

[2] P. M. Vermeersch, "'Out of Africa' from an Egyptian point of view," Quaternary International, vol. 75, pp. 103-112, 2001.

[3] P. Mellars, "Why did modern human populations disperse from Africa ca. 60,000 years ago? A new model," Proceedings of the National Academy of Sciences of the United States of America, vol. 103, no. 25, pp. 9381-9386, 2006.

[4] P. Mellars, "Going east: new genetic and archaeological perspectives on the modern human colonization of Eurasia," Science, vol. 313, no. 5788, pp. 796-800, 2006.

[5] S. J. Armitage et al., "The southern route "Out of Africa": evidence for an early expansion of modern humans into Arabia," Science, vol. 331, no. 28, pp. 453-456, 2011. 
[6] J. G. Fleagle, Z. Assefa, F. H. Brown, and J. J. Shea, "Paleoanthropology of the Kibish Formation, southern Ethiopia: introduction," Journal of Human Evolution, vol. 55, no. 3, pp. 360-365, 2008.

[7] T. D. White, B. Asfaw, D. DeGusta et al., "Pleistocene Homo sapiens from Middle Awash, Ethiopia," Nature, vol. 423, no. 6941, pp. 742-747, 2003.

[8] C. A. Tryon, “"Early" Middle Stone Age lithic technology of the Kapthurin Formation (Kenya)," Current Anthropology, vol. 47, no. 2, pp. 367-375, 2006.

[9] P. R. Willoughby, The Evolution of Modern Humans in Africa: A Comprehensive Guide, Altamira, New York, NY, USA, 2007.

[10] F. A. Reed and S. A. Tishkoff, "African human diversity, origins and migrations," Current Opinion in Genetics \& Development, vol. 16, no. 6, pp. 597-605, 2006.

[11] V. Macaulay, C. Hill, A. Achilli et al., "Single, rapid coastal settlement of Asia revealed by analysis of complete mitochondrial genomes," Science, vol. 308, no. 5724, pp. 1034-1036, 2005.

[12] J. I. Rose, "New light on human prehistory in the AraboPersian Gulf Oasis," Current Anthropology, vol. 51, no. 6, pp. 849-883, 2010.

[13] A. Beyin, "The Bab al Mandab vs the Nile-Levant: an appraisal of the two dispersal routes for early modern humans out of Africa," African Archaeological Review, vol. 23, no. 1-2, pp. 5-30, 2006.

[14] J. R. Luis, D. J. Rowold, M. Regueiro et al., "The Levant versus the Horn of Africa: evidence for bidirectional corridors of human migrations," American Journal of Human Genetics, vol. 74, no. 3, pp. 532-544, 2004.

[15] J. I. Rose, "The question of upper pleistocene connections between East Africa and South Arabia," Current Anthropology, vol. 45, no. 4, pp. 551-555, 2004.

[16] A. Marks, "Upper Pleistocene archaeology and the origins of modern man: a view from the Levant and adjacent areas," in The Evolution and Dispersal of Modern Humans in Asia, T. Akazawa, K. Aoki, and T. Kimura, Eds., pp. 229-251, Hokusen-Sha, Tokyo, Japan, 1992.

[17] P. Van Peer, "The nile corridor and the out-of-Africa model: an examination of the archaeological record," Current Anthropology, vol. 39, no. 1, pp. S115-S140, 1998.

[18] S. Semaw, P. Renne, J. W. K. Harris et al., "2.5-million-yearold stone tools from Gona, Ethiopia," Nature, vol. 385, no. 6614, pp. 333-336, 1997.

[19] I. McDougall, F. H. Brown, and J. G. Fleagle, "Stratigraphic placement and age of modern humans from Kibish, Ethiopia," Nature, vol. 433, no. 7027, pp. 733-736, 2005.

[20] L. E. Morgan and P. R. Renne, "Diachronous dawn of Africa's Middle Stone Age: new Ar/Ar ages from the Ethiopian Rift," Geology, vol. 36, no. 12, pp. 967-970, 2008.

[21] R. Cann, "DNA and human origins," in Annual Review of Anthropology, B. Siegel, A. Beals, and S. Tyler, Eds., pp. 127143, Annual Reviews, Palo Alto, Calif, USA, 1988.

[22] A. C. Wilson and R. L. Cann, "The recent African genesis of humans," Scientific American, vol. 266, no. 4, pp. 68-73, 1992.

[23] H. C. Harpending et al., "The genetic structure of ancient human populations," Current Anthropology, vol. 34, pp. 483496, 1993.

[24] C. Gamble, W. Davies, P. Pettitt, and M. Richards, "Climate change and evolving human diversity in Europe during the last glacial," Philosophical Transactions of the Royal Society B, vol. 359, no. 1442, pp. 243-254, 2004.

[25] S. L. Carto, A. J. Weaver, R. Hetherington, Y. Lam, and E. C. Wiebe, "Out of Africa and into an ice age: on the role of global climate change in the late Pleistocene migration of early modern humans out of Africa," Journal of Human Evolution, vol. 56, no. 2, pp. 139-151, 2009.

[26] C. Finlayson, "Biogeography and evolution of the genus Homo," Trends in Ecology and Evolution, vol. 20, no. 8, pp. 457-463, 2005.

[27] A. Powell, S. Shennan, and M. G. Thomas, "Late Pleistocene demography and the appearance of modern human behavior," Science, vol. 324, no. 5932, pp. 1298-1301, 2009.

[28] S. H. Ambrose, "Late Pleistocene human population bottlenecks, volcanic winter, and differentiation of modern humans," Journal of Human Evolution, vol. 34, no. 6, pp. 623651, 1998.

[29] S. McBrearty and A. S. Brooks, “The revolution that wasn't: a new interpretation of the origin of modern human behavior," Journal of Human Evolution, vol. 39, no. 5, pp. 453-563, 2000.

[30] J. J. Shea and M. L. Sisk, "Complex projectile technology and Homo sapiens dispersal into western Eurasia," PaleoAnthropology, vol. 2010, pp. 100-122, 2010.

[31] R. G. Klein, "Why anatomically modern people did not disperse from Africa 100,000 years ago," in Neandertals and Modern Humans in Western Asia, T. Akazawa, K. Aoki, and O. Bar-Yosef, Eds., pp. 509-521, Plenum Press, New York, NY, USA, 1998

[32] P. G. Chase, The Emergence of Culture: The Evolution of a Uniquely Human Way of Life, Springer, New York, NY, USA, 2006.

[33] F. D’Errico, C. Henshilwood, G. Lawson et al., "Archaeological evidence for the emergence of language, symbolism, and music - an alternative multidisciplinary perspective," Journal of World Prehistory, vol. 17, no. 1, pp. 1-70, 2003.

[34] M. E. Lewis and L. Werdelin, "Carnivoran dispersal out of Africa during the early Pleistocene: relevance for hominins?" in Out of Africa I: The First Hominin Colonization of Eurasia, J. G. Fleagle et al., Ed., pp. 13-26, Springer, Dordrecht, The Netherlands, 2010.

[35] B. Martínez-Navarro, "Early Pleistocene faunas of Eurasia and hominid dispersals," in Out of Africa I: The First Hominin Colonization of Eurasia, J. G. Fleagle et al., Ed., pp. 207-224, Springer, Dordrecht, The Netherlands, 2010.

[36] R. L. Cann, M. Stoneking, and A. C. Wilson, "Mitochondrial DNA and human evolution," Nature, vol. 325, no. 6099, pp. 31-36, 1987.

[37] E. K. Tripsanas, W. R. Bryant, N. C. Slowey, and J. W. Kim, "Marine isotope stage 6 canyon and spillover deposits of the Bryant and Eastern canyon systems, northwest Gulf of Mexico: importance of fine-grained turbidites on a delta-fed prograding slope," Journal of Sedimentary Research, vol. 76, no. 7-8, pp. 1012-1034, 2006.

[38] W. Liu et al., "Human remains from Zhirendong, South China, and modern human emergence in East Asia," Proceedings of the National Academy of Sciences of the United States of America, vol. 107, no. 45, pp. 19201-19206, 2010.

[39] B. Vandermeersch, "The Near Eastern hominids and the origins of modern humans in Eurasia," in The Evolution and Dispersal of Modern Humans in Asia, T. Akazawa, K. Aoki, and T. Kimura, Eds., pp. 29-38, Hokusen-sha Publishing, Tokyo, Japan, 1992.

[40] N. Mercier, H. Valladas, O. Bar-Yosef, B. Vandermeersch, C. Stringer, and J. L. Joron, "Thermoluminescence date for the Mousterian burial site of Es-Skhul, Mt. Carmel," Journal of Archaeological Science, vol. 20, no. 2, pp. 169-174, 1993.

[41] H. Valladas, J. L. Reyss, J. L. Joron, G. Valladas, O. BarYosef, and B. Vandermeersch, "Thermoluminescence dating 
of Mousterian Troto-Cro-Magnon' remains from Israel and the origin of modern man," Nature, vol. 331, no. 6157, pp. 614-616, 1988.

[42] O. Bar-Yosef, "The role of western Asia in modern human origins," Philosophical Transactions of the Royal Society B, vol. 337, no. 1280, pp. 193-200, 1992.

[43] C. B. M. McBurney, The Haua Fteah (Cyrenaica) and the Stone Age of the South-East Mediterranean, Cambridge University Press, Cambridge, UK, 1967.

[44] A. G. Parker, "Pleistocene climate change in Arabia: developing a framework for Hominin dispersal over the last $350 \mathrm{ka}$," in Evolution of Human Populations in Arabia: Paleoenvironments, Prehistory and Genetics, M. Petraglia and J. Rose, Eds., pp. 39-49, Springer, Dordrecht, The Netherlands, 2009.

[45] J. Kingdon, Self-Made Man: Human Evolution from Eden to Extinction, John Wiley \& Sons, New York, NY, USA, 1993.

[46] S. Oppenheimer, "The great arc of dispersal of modern humans: Africa to Australia," Quaternary International, vol. 202, no. 1-2, pp. 2-13, 2009.

[47] D. Bulbeck, "Where river meets sea: a parsimonious model for Homo sapiens colonization of the Indian Ocean Rim and Sahul," Current Anthropology, vol. 48, no. 2, pp. 315-321, 2007.

[48] M. Ingman and U. Gyllensten, "Mitochondrial genome variation and evolutionary history of Australian and New Guinean aborigines," Genome Research, vol. 13, no. 7, pp. 1600-1606, 2003.

[49] P. Forster, "Ice ages and the mitochondrial DNA chronology of human dispersals: a review," Philosophical Transactions of the Royal Society B, vol. 359, no. 1442, pp. 255-264, 2004.

[50] K. Thangaraj, G. Chaubey, V. K. Singh et al., "In situ origin of deep rooting lineages of mitochondrial Macrohaplogroup 'M' in India," BMC Genomics, vol. 7, article 151, 2006.

[51] P. Forster and S. Matsumura, "Did early humans go north or south?” Science, vol. 308, no. 5724, pp. 965-966, 2005.

[52] M. Metspalu, T. Kivisild, E. Metspalu et al., "Most of the extant mtDNA boundaries in South and Southwest Asia were likely shaped during the initial settlement of Eurasia by anatomically modern humans," BMC Genetics, vol. 5, no. 1, article 26, 2004.

[53] J. J. Shea, "Neandertals, competition, and the origin of modern human behavior in the Levant," Evolutionary Anthropology, vol. 12, no. 4, pp. 173-187, 2003.

[54] P. Mellars, "Archeology and the dispersal of modern humans in Europe: deconstructing the "Aurignacian"," Evolutionary Anthropology, vol. 15, no. 5, pp. 167-182, 2006.

[55] S. Mithen and M. Reed, "Stepping out: a computer simulation of hominid dispersal from Africa," Journal of Human Evolution, vol. 43, no. 4, pp. 433-462, 2002.

[56] R. Derricourt, "Getting "Out of Africa": sea crossings, land crossings and culture in the Hominin migrations," Journal of World Prehistory, vol. 19, no. 2, pp. 119-132, 2005.

[57] E. Tchernov, "Biochronology, paleoecology, and dispersal events of hominids in the southern Levant," in The Evolution and Dispersal of Modern Humans in Asia, T. Akazawa, K. Aoki, and T. Kimura, Eds., pp. 149-188, Hokusen-sha, Tokyo, Japan, 1992.

[58] O. Bar-Yosef and A. Belfer-Cohen, "From Africa to Eurasiaearly dispersals," Quaternary International, vol. 75, pp. 19-28, 2001.

[59] A. H. Osborne, D. Vance, E. J. Rohling, N. Barton, M. Rogerson, and N. Fello, "A humid corridor across the Sahara for the migration of early modern humans out of Africa 120,000 years ago," Proceedings of the National Academy of
Sciences of the United States of America, vol. 105, no. 43, pp. 16444-16447, 2008.

[60] J. S. Field and M. M. Lahr, "Assessment of the Southern Dispersal: GIS-based analyses of potential routes at oxygen isotopic stage 4," Journal of World Prehistory, vol. 19, no. 1, pp. 1-45, 2005.

[61] A. E. Marks, "Typological variability in the Levantine Middle Paleolithic," in The Middle Paleolithic: Adaptation, Behavior and Variability, H. L. Dibble and P. A. Mellars, Eds., pp. 127141, University of Pennsylvania Museum Press, Philadelphia, Pa, USA, 1992.

[62] J. F. O'Connell and J. Allen, "Dating the colonization of Sahul (Pleistocene Australia-New Guinea): a review of recent research," Journal of Archaeological Science, vol. 31, no. 6, pp. 835-853, 2004.

[63] C. S. M. Turney, M. I. Bird, L. K. Fifield et al., "Early human occupation at Devil's Lair, southwestern Australia 50,000 years ago," Quaternary Research, vol. 55, no. 1, pp. 3-13, 2001.

[64] R. E. Green, J. Krause, A. W. Briggs et al., "A draft sequence of the neandertal genome," Science, vol. 328, no. 5979, pp. 710-722, 2010.

[65] C. Stringer, "Coasting out of Africa," Nature, vol. 405, no. 6782, pp. 24-27, 2000.

[66] R. C. Walter, R. T. Buffler, J. H. Bruggemann et al., "Early human occupation of the Red Sea coast of Eritrea during the last interglacial," Nature, vol. 405, no. 6782, pp. 65-69, 2000.

[67] A. Beyin, Prehistoric Settlements on the Red Sea Coast of Eritrea: Archaeological Investigation of the Buri Peninsula and Gulf of Zula, Lambert Academic Publishing, Saarbrücken, Germany, 2010.

[68] A. Beyin and J. J. Shea, "Reconnaissance of prehistoric sites on the Red Sea coast of Eritrea, NE Africa," Journal of Field Archaeology, vol. 32, no. 1, pp. 1-16, 2007.

[69] A. E. Marks, "The Paleolithic of Arabia in an inter-regional context," in Evolution of Human Populations in Arabia: Paleoenvironments, Prehistory and Genetics, M. Petraglia and J. Rose, Eds., pp. 293-309, Springer, Dordrecht, The Netherlands, 2009.

[70] J. I. Rose and V. I. Usik, "The "Upper Paleolithic" of South Arabia," in Evolution of Human Populations in Arabia: Paleoenvironments, Prehistory and Genetics, M. Petraglia and J. Rose, Eds., pp. 169-186, Springer, Dordrecht, The Netherlands, 2009.

[71] B. J. Winney, R. L. Hammond, W. Macasero et al., "Crossing the Red Sea: phylogeography of the hamadryas baboon, Papio hamadryas hamadryas," Molecular Ecology, vol. 13, no. 9, pp. 2819-2827, 2004.

[72] C. A. Fernandes, "Bayesian coalescent inference from mitochondrial DNA variation of the colonization time of Arabia by the Hamadryas baboon (Papio hamadryas hamadryas)," in The Evolution of Human Populations in Arabia: Paleoenvironments, Prehistory and Genetics, M. D. Petraglia and J. I. Rose, Eds., pp. 89-100, Springer, Dordrecht, The Netherlands, 2009.

[73] H. Kummer, In Quest of the Sacred Baboon: A Scientist's Journey, Princeton University Press, Princeton, NJ, USA, 1995.

[74] J. Rose, "The Arabian Corridor Migration Model: archaeological evidence for hominin dispersals into Oman during the Middle and Upper Pleistocene," in Proceedings of the Seminar for Arabian Studies, vol. 37, pp. 1-19, 2007.

[75] C. A. Fernandes, E. J. Rohling, and M. Siddall, "Absence of post-Miocene Red Sea land bridges: biogeographic implications," Journal of Biogeography, vol. 33, no. 6, pp. 961-966, 2006. 
[76] F. Bordes, "Reflections on technology and techniques in the Paleolithic," Arctic Anthropology, vol. 6, no. 1, pp. 1-29, 1969.

[77] F. Bordes and D. de Sonneville-Bordes, "The significance of variability in Paleolithic assemblages," World Archaeology, vol. 2, no. 1, pp. 61-73, 1970.

[78] M. R. Kleindienst, "On the Nile corridor and the Out-of Africa Model," Current Anthropology, vol. 41, pp. 107-109, 2000.

[79] K. Westley and J. Dix, "Coastal environments and their role in prehistoric migrations," Journal of Maritime Archaeology, vol. 1, no. 1, pp. 9-28, 2006.

[80] M. Siddall, E. J. Rohling, A. Almogi-Labin et al., "Sea-level fluctuations during the last glacial cycle," Nature, vol. 423, no. 6942, pp. 853-858, 2003.

[81] F. Wendorf, A. Close, and R. Schild, "Africa in the period of Homo sapiens neanderthalensis and contemporaries," in History of Humanity, Vol. 1, Prehistory and the Beginnings of Civilization, S. J. De Laet, Ed., pp. 117-135, Routledge, New York, NY, USA, 1994.

[82] J. D. Clark, "The Middle Stone Age of East Africa and the beginnings of regional identity," Journal of World Prehistory, vol. 2, no. 3, pp. 235-305, 1988.

[83] E. Boëda, "Le Concept Levallois et évaluation de son champ d'application," in L'homme de Neandertal. Vol. 4 La Technique, M. Otte, Ed., pp. 13-26, ERAUL, Liège, Belgium, 1988.

[84] S. H. Ambrose, "Howiesons Poort lithic raw material procurement patterns and the evolution of modern human behavior: a response to Minichillo (2006)," Journal of Human Evolution, vol. 50, no. 3, pp. 365-369, 2006.

[85] C. S. Henshilwood, F. D’Errico, R. Yates et al., "Emergence of modern human behavior: middle stone age engravings from South Africa," Science, vol. 295, no. 5558, pp. 1278-1280, 2002.

[86] C. W. Marean, M. Bar-Matthews, J. Bernatchez et al., "Early human use of marine resources and pigment in South Africa during the Middle Pleistocene," Nature, vol. 449, no. 7164, pp. 905-908, 2007.

[87] A. S. Brooks et al., "Projectile technologies of the African MSA: implications for modern human origins," in Transitions before the Transition: Evolution and Stability in the Middle Paleolithic and Middle Stone Age, E. Hovers and S. L. Kuhn, Eds., pp. 233-255, Springer, New York, NY, USA, 2006.

[88] J. J. Shea, "The origins of lithic projectile point technology: evidence from Africa, the Levant, and Europe," Journal of Archaeological Science, vol. 33, no. 6, pp. 823-846, 2006.

[89] J. J. Shea, "The middle stone age archaeology of the lower Omo Valley Kibish formation: excavations, lithic assemblages, and inferred patterns of early Homo sapiens behavior," Journal of Human Evolution, vol. 55, no. 3, pp. 448-485, 2008.

[90] J. I. Rose, "The role of the Saharo-Arabian arid belt in the modern human expansion, in from the Mediterranean Basin to the Portuguese Atlantic shore," in Papers in Honor of Anthony Marks Actas do IV Congresso de Arqueologia Peninsular, N. Bicho and P. Acker, Eds., Universidade do Algarve Promontoria Monografica 07, Faro, Portugal, 2006.

[91] O. Bar-Yosef, "Pleistocene connexions between Africa and Southwest Asia: an archaeological perspective," The African Archaeological Review, vol. 5, no. 1, pp. 29-38, 1987.

[92] O. Bar-Yosef, "The contributions of Southwest Asia to the study of the origin of modern humans," in Origins of Anatomically Modern Humans, M. H. Nitecki and D. V. Nitecki, Eds., pp. 23-66, Plenum, New York, NY, USA, 1994.
[93] E. Tchernov, "Eurasian-African biotic exchanges through the Levantine corridor during the Neogene and Quaternary," Courier Forschungsinstitut Senckenberg, vol. 153, pp. 103123, 1992.

[94] E. Tchernov and E. Tsoukala, "Middle Pleistocene (Early Toringian) Carnivore Remains from Northern Israel," Quaternary Research, vol. 48, no. 1, pp. 122-136, 1997.

[95] M. Belmaker, "Early Pleistocene faunal connections between Africa and Eurasia: an ecological perspective," in Out of Africa I: The First Hominin Colonization of Eurasia, J. G. Fleagle et al., Ed., pp. 183-206, Springer, Dordrecht, The Netherlands, 2010.

[96] E. Trinkaus, "Western Asia," in The Origins of Modern Humans, F. H. Smith and F. Spencer, Eds., pp. 251-293, Alan R. Liss, New York, NY, USA, 1984.

[97] N. Mercier and H. Valladas, "Reassessment of TL age estimates of burnt flints from the Paleolithic site of Tabun Cave, Israel," Journal of Human Evolution, vol. 45, no. 5, pp. 401-409, 2003.

[98] H. Valladas, N. Mercier, L. Froget et al., "TL dates for the Neanderthal site of the Amud Cave, Israel," Journal of Archaeological Science, vol. 26, no. 3, pp. 259-268, 1999.

[99] J. J. Shea, "Neandertal and early modern human behavioral variability a regional-scale approach to lithic evidence for hunting in the Levantine Mousterian," Current Anthropology, vol. 39, no. 1, pp. S45-S78, 1998.

[100] K. Monigal, "The Levantine leptolithic: blade technology from the Lower Palaeolithic to the dawn of the Upper Palaeolithic," in Anthropology, Southern Methodist University, Dallas, Tex, USA, 2002.

[101] A. J. Jelinek, "The Middle Paleolithic in the Southern Levant from the perspective of the Tabun Cave," in Préhistoire du Levant, J. Cauvin and P. Sanlaville, Eds., pp. 265-279, Editions du CNRS, Paris, France, 1981.

[102] A. J. Jelinek, "The Tabun cave and Paleolithic man in the Levant," Science, vol. 216, no. 4553, pp. 1369-1375, 1982.

[103] M. D. Petraglia and J. I. Rose, "Tracking the origin and evolution of human populations in Arabia," in The Evolution of Human Populations in Arabia: Paleoenvironments, Prehistory and Genetics, M. D. Petraglia and J. I. Rose, Eds., Springer, Dordrecht, The Netherlands, 2009.

[104] J. I. Rose, "Among Arabian sands: defining the Palaeolithic of southern Arabia," in Anthropology, Southern Methodist University, Dallas, Tex, USA, 2006.

[105] A. Delagnes et al., "Middle Paleolithic settlement in Arabia: first evidence from a complex of stratified archaeological sites in western Yemen," in Paper Presented at the Meeting of the Paleoanthropology Society, Vancouver, Canada, March 2008.

[106] G. Bailey, "The Red Sea, coastal landscapes, and hominin dispersals," in The Evolution of Human Populations in Arabia: Paleoenvironments, Prehistory and Genetics, M. D. Petraglia and J. I. Rose, Eds., pp. 15-38, Springer, New York, NY, USA, 2009.

[107] H. Faure, R. C. Walter, and D. R. Grant, "The coastal oasis: ice age springs on emerged continental shelves," Global and Planetary Change, vol. 33, no. 1-2, pp. 47-56, 2002.

[108] V. Černý, C. J. Mulligan, J. Rídl et al., "Regional differences in the distribution of the sub-Saharan, West Eurasian, and South Asian mtDNA lineages in Yemen," American Journal of Physical Anthropology, vol. 136, no. 2, pp. 128-137, 2008.

[109] K. K. Abu-Amero, A. M. Gonźlez, J. M. Larruga, T. M. Bosley, and V. M. Cabrera, "Eurasian and African mitochondrial DNA influences in the Saudi Arabian population," BMC Evolutionary Biology, vol. 7, article 32, 2007. 
[110] V. N. Misra, "Prehistoric human colonization of India," Journal of Biosciences, vol. 26, no. 4, pp. 491-531, 2001.

[111] S. Pappu, A Re-Examination of the Palaeolithic, Bar International Series 1003, Archaeological Record of Northern Tamil Nadu, South India, 2001.

[112] S. S. Patel, "Stone age India," in Archaeology Magazine, pp. 28-34, Archaeological Institute of America, Washington, DC, USA, 2010.

[113] G. Barker, H. Barton, M. Bird et al., “The 'human revolution' in lowland tropical Southeast Asia: the antiquity and behavior of anatomically modern humans at Niah Cave (Sarawak, Borneo)," Journal of Human Evolution, vol. 52, no. 3, pp. 243-261, 2007.

[114] J. M. Bowler, H. Johnston, J. M. Olley et al., "New ages for human occupation and climatic change at Lake Mungo, Australia," Nature, vol. 421, no. 6925, pp. 837-840, 2003.

[115] M. V. Oven and M. Kayser, "Updated comprehensive phylogenetic tree of global human mitochondrial DNA variation," Human Mutation, vol. 1039, no. 30, pp. E386-E394, 2008.

[116] E. Watson, P. Forster, M. Richards, and H. J. Bandelt, "Mitochondrial footprints of human expansions in Africa," American Journal of Human Genetics, vol. 61, no. 3, pp. 691-704, 1997.

[117] H. C. Harpending, M. Batzer, M. Gurven, L. B. Jorde, A. R. Rogers, and S. T. Sherry, "Genetic traces of ancient demography," Proceedings of the National Academy of Sciences of the United States of America, vol. 95, no. 4, pp. 1961-1967, 1998.

[118] B. Pakendorf and M. Stoneking, "Mitochondrial DNA and human evolution," Annual Review of Genomics and Human Genetics, vol. 6, pp. 165-183, 2005.

[119] R. J. Mitchell and M. F. Hammer, "Human evolution and the Y chromosome," Current Opinion in Genetics and Development, vol. 6, no. 6, pp. 737-742, 1996.

[120] S. T. Sherry, H. C. Harpending, M. A. Batzer, and M. Stoneking, "Alu evolution in human populations: using the coalescent to estimate effective population size," Genetics, vol. 147, no. 4, pp. 1977-1982, 1997.

[121] A. Torroni, A. Achilli, V. Macaulay, M. Richards, and H. J. Bandelt, "Harvesting the fruit of the human mtDNA tree," Trends in Genetics, vol. 22, no. 6, pp. 339-345, 2006.

[122] V. M. Cabrera et al., "The Arabian peninsula: gate for human migrations out of Africa or Cul-de-Sac? A mitochondrial DNA phylogeographic perspective," in The Evolution of Human Populations in Arabia: Paleoenvironments, Prehistory and Genetics, M. D. Petraglia and J. I. Rose, Eds., pp. 79-88, Springer, Dordrecht, The Netherlands, 2009.

[123] L. Quintana-Murci, O. Semino, H. J. Bandelt, G. Passarino, K. McElreavey, and A. S. Santachiara-Benerecetti, "Genetic evidence of an early exit of Homo sapiens sapiens from Africa through eastern Africa," Nature Genetics, vol. 23, no. 4, pp. 437-441, 1999.

[124] N. Maca-Meyer, A. M. González, J. M. Larruga, C. Flores, and V. M. Cabrera, "Major genomic mitochondrial lineages delineate early human expansions," BMC Genetics, vol. 2, article 13, 2001.

[125] A. Olivieri, A. Achilli, M. Pala et al., "The mtDNA legacy of the Levantine early Upper Palaeolithic in Africa," Science, vol. 314, no. 5806, pp. 1767-1770, 2006.

[126] A. M. González, J. M. Larruga, K. K. Abu-Amero, Y. Shi, J. Pestano, and V. M. Cabrera, "Mitochondrial lineage M1 traces an early human backflow to Africa," BMC Genomics, vol. 8, article 223, 2007.

[127] J. Rídl, C. M. Edens, and V. Černý, "Mitochondrial DNA structure of Yemeni population: regional differences and the implications for different migratory contributions," in The Evolution of Human Populations in Arabia: Paleoenvironments, Prehistory and Genetics, M. D. Petraglia and J. I. Rose, Eds., pp. 69-78, Springer, Dordrecht, The Netherlands, 2009.

[128] F. Cruciani, P. Santolamazza, P. Shen et al., "A back migration from Asia to sub-Saharan Africa is supported by high-resolution analysis of human Y-chromosome haplotypes," American Journal of Human Genetics, vol. 70, no. 5, pp. 1197-1214, 2002.

[129] T. K. Altheide and M. F. Hammer, "Evidence for a possible Asian origin of YAP Y chromosomes," American Journal of Human Genetics, vol. 61, no. 2, pp. 462-466, 1997.

[130] H.-P. Uerpmann et al., "Preliminary results of the excavations at Jebel Faya (Sharjah): 2003-2008," in Paper Presented in Al Ain, April 2008.

[131] M. A. Schillaci, "Human cranial diversity and evidence for an ancient lineage of modern humans," Journal of Human Evolution, vol. 54, no. 6, pp. 814-826, 2008.

[132] D. J. Rowold, J. R. Luis, M. C. Terreros, and R. J. Herrera, "Mitochondrial DNA geneflow indicates preferred usage of the Levant Corridor over the Horn of Africa passageway," Journal of Human Genetics, vol. 52, no. 5, pp. 436-447, 2007.

[133] S. M. van Holst Pellekaan, M. Ingman, J. Roberts-Thomson, and R. M. Harding, "Mitochondrial genomics identifies major haplogroup in Aboriginal Australians," American Journal of Physical Anthropology, vol. 131, no. 2, pp. 282-294, 2006.

[134] J. Rídl, "New light on human prehistory in the Arabo-Persian Gulf Oasis. Commentary," Current Anthropology, vol. 51, no. 6, pp. 872-873, 2010.

[135] R. Potts, "Evolution and climate variability," Science, vol. 273, no. 5277, pp. 922-923, 1996.

[136] E. S. Vrba, "Environment and evolution: alternative causes of the temporal distribution of evolutionary events," South African Journal of Science, vol. 81, pp. 229-236, 1985.

[137] W. F. Keegan and J. M. Diamond, "Colonization of islands by humans: a biogeographical perspective," Advances in Archaeological Method and Theory, vol. 10, pp. 49-91, 1987.

[138] G. Bailey and J. Parkington, Eds., The Archaeology of Prehistoric Coastlines, Cambridge University Press, Cambridge, UK, 1988.

[139] J. M. Erlandson, “The Archaeology of aquatic adaptations: paradigms for a new millennium," Journal of Archaeological Research, vol. 9, no. 4, pp. 287-350, 2001.

[140] C. O. Sauer, "Seashore-primitive home of man?" in Land and Life: A Selection from the writings of Carl Ortwin Sauer, J. Leighly, Ed., University of California Press, Berkeley, Calif, USA, 1963.

[141] K. Lambeck and J. Chappell, "Sea level change through the last glacial cycle," Science, vol. 292, no. 5517, pp. 679-686, 2001.

[142] A. Thorne, R. Grün, G. Mortimer et al., "Australia’s oldest human remains: age of the Lake Mungo 3 skeleton," Journal of Human Evolution, vol. 36, no. 6, pp. 591-612, 1999.

[143] T. H. Van Andel, "Late quaternary sea-level changes and archaeology," Antiquity, vol. 63, no. 241, pp. 733-745, 1989.

[144] D. J. Mulvaney and J. Kamminga, Prehistory of Australia, Allen and Unwin, Sydney, Australia, 1999.

[145] E. James Dixon, "Human colonization of the Americas: timing, technology and process," Quaternary Science Reviews, vol. 20, no. 1-3, pp. 277-299, 2001.

[146] C. W. Marean, "When the sea saved humanity," Scientific American, vol. 303, no. 2, pp. 54-61, 2010. 
[147] R. Singer and J. Wymer, The Middle Stone Age at Klasies River Mouth in South Africa, University of Chicago Press, Chicago, Ill, USA, 1982.

[148] P. Goldberg, "Micromorphology and site formation at Die Kelders Cave I, South Africa," Journal of Human Evolution, vol. 38, no. 1, pp. 43-90, 2000.

[149] J. S. Brink and H. J. Deacon, "A study of a last interglacial shell middens and bone accumulation at Herolds Bay, cape province, South Africa," Paleoecology of Africa, vol. 15, pp. 31-40, 1982.

[150] C. Henshilwood and J. Sealy, "Bone artefacts from the middle stone age at Blombos Cave, Southern Cape, South Africa," Current Anthropology, vol. 38, no. 5, pp. 890-895, 1997.

[151] T. P. Volman, "Early archeological evidence for shellfish collecting," Science, vol. 201, no. 4359, pp. 911-913, 1978.

[152] C. Richter, H. Roa-Quiaoit, C. Jantzen, M. Al-Zibdah, and M. Kochzius, "Collapse of a new living species of giant clam in the Red Sea," Current Biology, vol. 18, no. 17, pp. 1349-1354, 2008.

[153] A. E. Marks, "The Middle Paleolithic of the near East and the Nile Valley: the problem of cultural transformations," in The Emergence of Modern Humans, P. Mellars, Ed., pp. 56-80, Edinburgh University Press, Edinburgh, UK, 1990.

[154] J. I. Rose, "New evidence for the expansion of an upper pleistocene population out of East Africa, from the site of station one, Northern Sudan," Cambridge Archaeological Journal, vol. 14, no. 2, pp. 205-216, 2004.

[155] D. M. Petraglia and A. Alsharekh, "The Middle Paleolithic of Arabia: implications for modern human origins, behavior and dispersals," Antiquity, vol. 77, no. 298, pp. 671-684, 2003. 

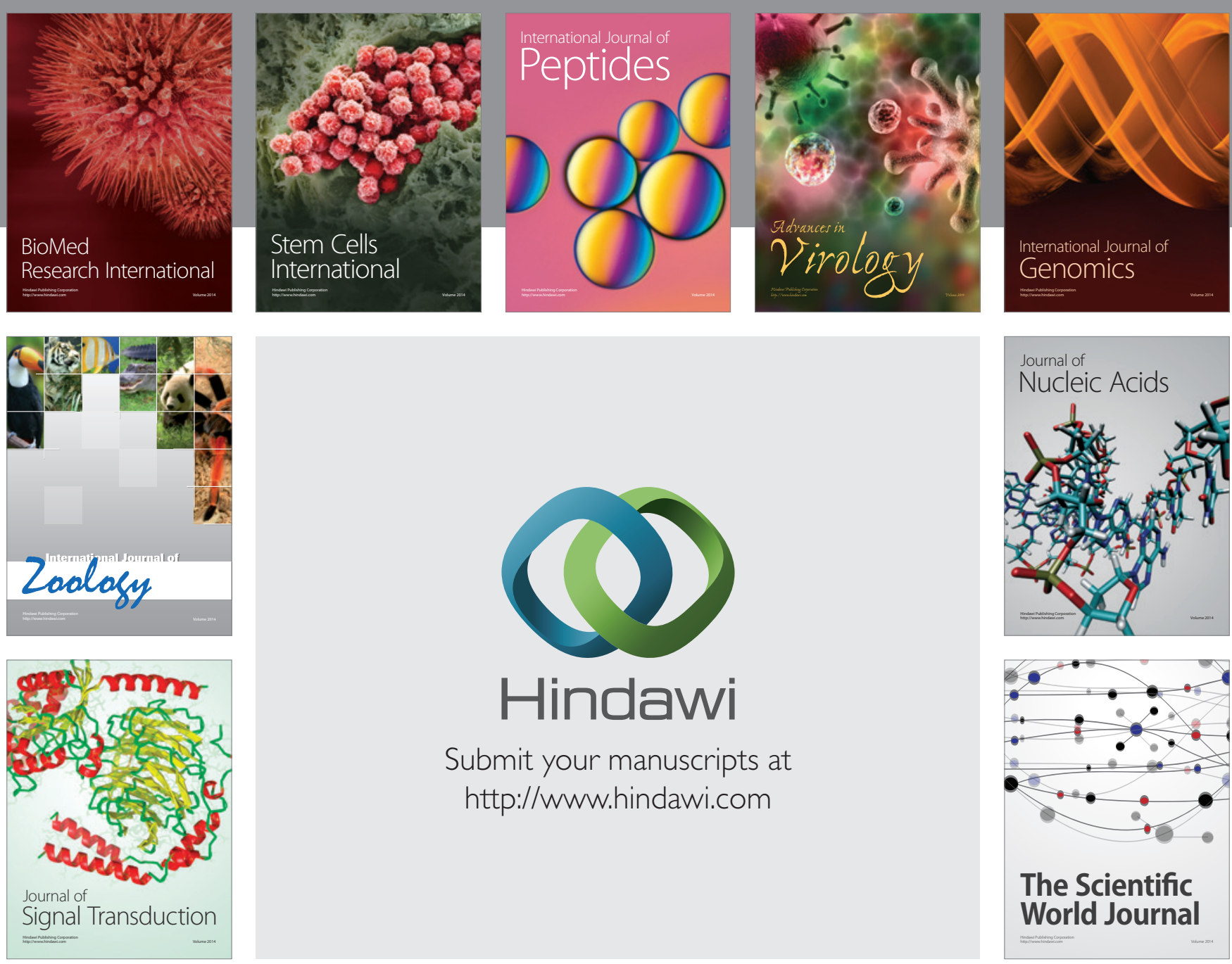

Submit your manuscripts at

http://www.hindawi.com
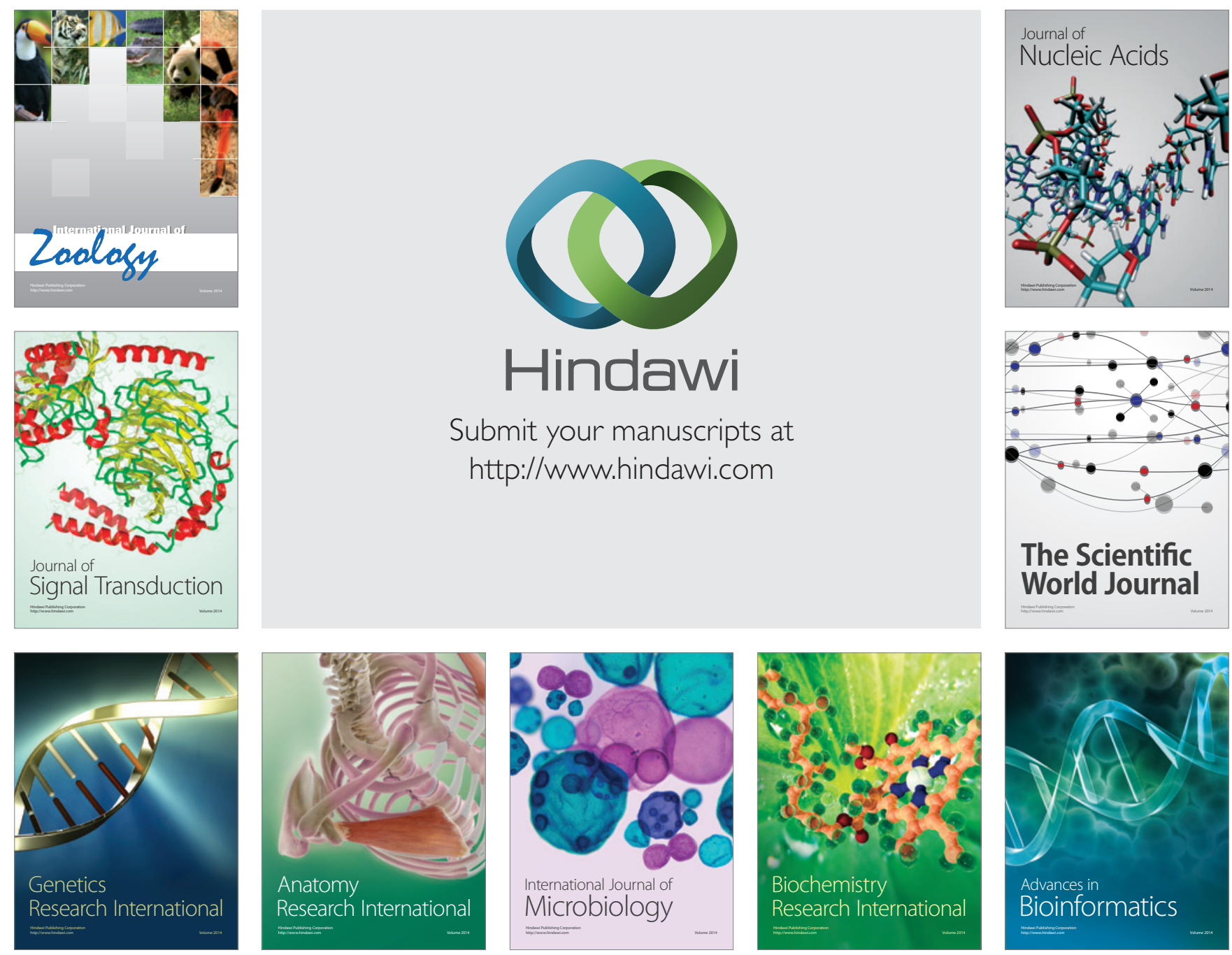

The Scientific World Journal
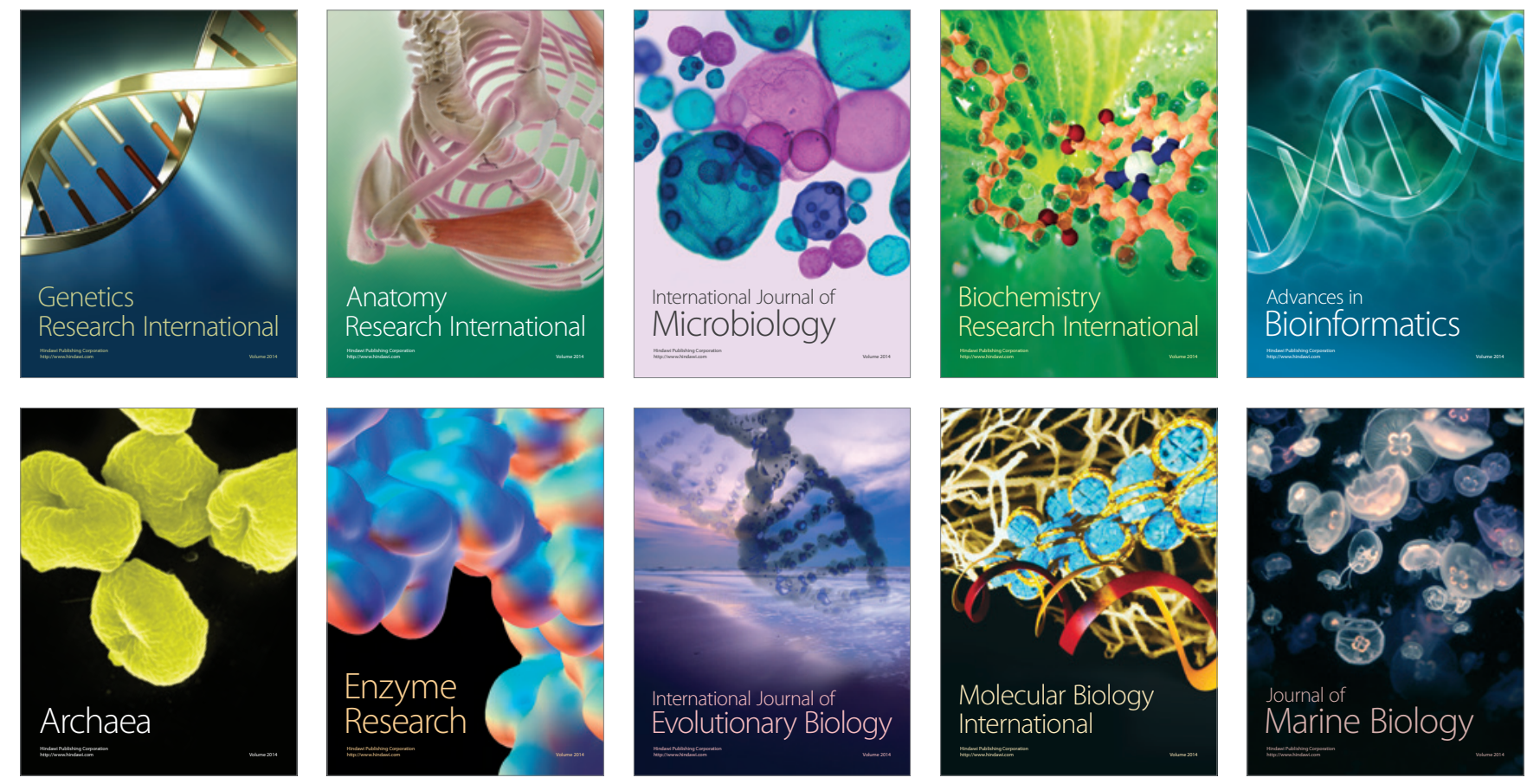